University of Pennsylvania Carey Law School

Penn Law: Legal Scholarship Repository

Faculty Scholarship at Penn Law

1989

\title{
The Qualified Immunity Doctrine in the Supreme Court: Judicial Activism and the Restriction of Constitutional Rights
}

David Rudovsky

University of Pennsylvania Carey Law School

Follow this and additional works at: https://scholarship.law.upenn.edu/faculty_scholarship

Part of the Civil Rights and Discrimination Commons, Constitutional Law Commons, Legal Remedies Commons, Litigation Commons, State and Local Government Law Commons, and the Torts Commons

\section{Repository Citation}

Rudovsky, David, "The Qualified Immunity Doctrine in the Supreme Court: Judicial Activism and the Restriction of Constitutional Rights" (1989). Faculty Scholarship at Penn Law. 1507.

https://scholarship.law.upenn.edu/faculty_scholarship/1507

This Article is brought to you for free and open access by Penn Law: Legal Scholarship Repository. It has been accepted for inclusion in Faculty Scholarship at Penn Law by an authorized administrator of Penn Law: Legal Scholarship Repository. For more information, please contact PennlawIR@law.upenn.edu. 


\title{
ARTICLE
}

\section{THE QUALIFIED IMMUNITY DOCTRINE IN THE SUPREME COURT: JUDICIAL ACTIVISM AND THE RESTRICTION OF CONSTITUTIONAL RIGHTS}

\author{
DAvid RuDovsKy $\dagger$
}

\section{INTRODUCTION}

More than twenty-five years after its watershed decision in Monroe v. Pape, ${ }^{1}$ the Supreme Court continues to struggle with the doctrinal, political, and institutional consequences of this resurrection of the Civil Rights Act. ${ }^{2}$ In the immediate aftermath of Monroe,

† Senior Fellow, University of Pennsylvania Law School. Partner, Kairys \& Rudovsky. B.A. 1964, Queens College (CUNY); LL.B. 1967, New York University School of Law. I am indebted to Michael Avery. For the past fifteen years, as cocounsel in civil rights litigation and co-authors of Police Misconduct: Law and Litigation (1980), we have discussed, seemingly endlessly, the issue of qualified immunity. His contributions to this Article are many. I have also benefited from the comments of Seth Kreimer, Susan Sturm, David Kairys, Dan Jonas, Adam Thurschwell, and the members of the University of Pennsylvania Ad Hoc Forum on Legal Scholarship.

The author argued before the Supreme Court on behalf of the respondents in two cases discussed in this Article: City of Canton v. Harris, 109 S. Ct. 1197 (1989), and Mitchell v. Forsyth, 472 U.S. 511 (1985).

1365 U.S. 167 (1961), ovemuled in part, Monell v. New York Dep't of Social Servs., 436 U.S. 658 (1978).

242 U.S.C. $\S 1983$ (1982) (originally enacted as Act of April 20, 1871, ch. 22, $\S 1,17$ Stat. 13). The Act provides:

Every person who, under color of any statute, ordinance, regulation, custom, or usage, of any State or Territory or the District of Columbia, subjects, or causes to be subjected, any citizen of the United States or other person within the jurisdiction thereof to the deprivation of any rights, privileges, or immunities secured by the Constitution and laws, shall be liable to the party injured in an action at law, suit in equity, or other proper proceeding for redress. For the purposes of this section, any Act of Congress applicable exclusively to the District of Columbia shall be considered to be a statute of the District of Columbia.

Id.

Popularly known as the Ku Klux Act of 1871 , Congress enacted $\S 1983$ to provide federal power to fight the "Klan's reign of terror." Jett v. Dallas Indep. School Dist., 109 S. Ct. 2702, 2715-16 (1989). The Court provided the first modern interpretation of this section in Hague v. CIO, 307 U.S. 496 (1939), but the Act was largely ignored until Monroe. It is now well established that $\S 1983$ was "designed to 
the Court resolved important threshold issues of the Act's coverage in a manner that provided wide access to the federal courts to remedy constitutional violations. The Court gave a broad reading to the concepts of state action and color of state law, ${ }^{3}$ ruled that property as well as liberty interests were protected by the Act, ${ }^{4}$ determined that exhaustion of state remedies was not required, ${ }^{5}$ and provided only limited immunities to individual defendants. ${ }^{6}$ With the Court's contemporaneous expansion of substantive constitutional protections, ${ }^{7}$

expose state and local officials to a new form of liability." Newport v. Fact Concert, Inc., 453 U.S. 247, 259 (1981); see also Mitchum v. Foster, 407 U.S. 225, 239 (1972) (noting that $\S 1983$ created a "uniquely federal remedy" against constitutional violations by state actors).

Section 1 of the 1871 Act was one of several Reconstruction-era statutes providing federal civil remedies and criminal penalties for violations of constitutional rights by state actors or private persons. See 42 U.S.C. $\$ \S 1981,1982,1985,1986 \& 1988$ (1982). See generally Jett, $109 \mathrm{~S}$. Ct. at 2720-21 (holding that the express cause of action for damages created by $\$ 1983$ constitutes the exclusive federal remedy for violations of $\$ 1981$ ); Maine v. Thiboutot, 448 U.S. 1, 16 (1980) (holding that the rights protected by $\S 1983$ include the right to receive welfare benefits by those who are entitled by law to such payments); Monell v. New York Dep't of Social Servs., 436 U.S. 658, 664 (1978) (holding that municipalities are "persons" for the purposes of $\$ 1$ 1983); Kreimer, The Source of Law in Civil Rights Actions: Some Old Light on Section 1988,133 U. PA. L. REv. 601 (1985) (arguing that the drafting of $\S 1983$ provided little framework for the determination of appropriate causes of action or the extent and conditions of liability under the law).

3 See, e.g., Adickes v. S.H. Kress \& Co., 398 U.S. 144 (1970) (holding that a white plaintiff, denied service because she was in the company of a group of blacks, could seek redress under $\S 1983$ by showing that the existence of state-enforced segregationist policies motivated the defendant); Reitman v. Mulkey, 387 U.S. 369 (1967) (determining that discrimination in the selling or leasing of real estate violates the fourteenth amendment); Burton v. Wilmington Parking Auth., 365 U.S. 715 (1961) (holding that the racially-motivated exclusion of blacks from a restaurant that is privately owned but located in a state-owned building constitutes discriminatory state action subject to $\S 1983$ ).

4 See Lynch v. Household Fin. Corp., 405 U.S. 538, 552 (1972) (recognizing that "rights in property are basic civil rights" protected by $\$ 1983$ ).

5 See Patsy v. Board of Regents, 457 U.S. 496, 512 (1982) (holding that, with a few specific exceptions carved out by Congress, the exhaustion of state administrative remedies is not a prerequisite to action under $\$ 1983$ ); McNeese v. Board of Educ., 373 U.S. 668, 676 (1963) (holding that when federal rights are subject to the uncertain protection of state and local officials, resort to a state proceeding before seeking federal relief is unnecessary).

6 See, e.g., Pierson v. Ray, 386 U.S. 547, 553-54, 557 (1967) (holding that judges are immune from liability stemming from unconstitutional acts committed within their judicial discretion, and that police officers who make a false arrest are immune if the arrest was executed with good faith and probable cause), modified, Harlow v. Fitzgerald, 457 U.S. 800 (1982).

7 See, e.g., Estelle v. Gamble, 429 U.S. 97 (1976) (eighth amendment); Board of Regents v. Roth, 408 U.S. 564 (1972) (due process); Goldberg v. Kelly, 397 U.S. 254 (1970) (due process); Chimel v. California, 395 U.S. 752 (1969) (fourth amendment); Katz v. United States, 389 U.S. 347 (1967) (fourth amendment); United States v. 
$\S 1983$ became the statute of choice for the litigation of constitutional tort actions. ${ }^{8}$

In recent years the Court has refined the scope of federal court jurisdiction over claims of governmental misconduct and, in particular, has limited the power of federal courts to monitor or regulate the functions of state and local governments. ${ }^{9}$ As a matter of substantive constitutional doctrine, the Court has drawn distinct lines between what it considers state law wrongs and constitutional torts, and has relegated the former to the arena of state tort remedies. ${ }^{10}$

Beyond the narrowing of constitutionally protected liberty and property rights, the Court also has engaged in an aggressive reconstruction of the scope of $\S 1983$. This reorientation of civil rights

Wade, 388 U.S. 218 (1967) (sixth amendment, due process); New York Times v. Sullivan, 376 U.S. 254 (1964) (first amendment, due process); Brown v. Board of Educ. 347 U.S. 483 (1954) (equal protection); see also Blackmun, Section 1983 and Federal Protection of Civil Rights - Will the Statute Remain Alive or Fade Away?, 60 N.Y.U. L. REv. 1, 19-20 (1985) (describing the expanding significance of $\S 1983$ in civil liberties litigation).

8 In 1960, approximately 300 civil rights suits were filed in federal court. See 1960 Annual Report of the Director of the Administrative Office of The United States Courts 232, at table C-2 (1960). In 1987, 19,785 civil rights suits were filed in the federal courts. See 1987 Annual Report of the Director of the Administrative Office of the United States Courts 178, at table C-2 (1987).

9 See, e.g., DeShaney v. Winnebago County Dep't of Social Servs., 109 S. Ct. 998, 1007 (1989) (observing that the due process clause of the fourteenth amendment "does not transform every tort committed by a state actor into a constitutional violation"); City of Los Angeles v. Lyons, 461 U.S. 95, 111-12 (1983) (declaring that federal courts should exercise restraint in issuing injunctions against state police officials engaged in the administration of criminal laws unless the consequences of such administration are "both great and immediate"); Parratt v. Taylor, 451 U.S. 527, 543-44 (1981) (holding that although taking of property was a due process violation, post-taking hearing provided by the state satisfied constitutional requirements), overruled in part, Daniels v. Williams, 474 U.S. 327 (1986); Paul v. Davis, 424 U.S. 693, 711-12 (1976) (holding that defamation by local police is not, by itself, a constitutional violation); Younger v. Harris, 401 U.S. 37, 50-51 (1971) (denying injunctive relief to a plaintiff who claimed that the unconstitutional prosecution of a third party chilled his first amendment rights).

10 See, e.g., DeShaney, $109 \mathrm{~S}$. Ct. at 1005 (finding no duty to protect individuals not in custody of the state); Daniels, 474 U.S. at 330-31 (construing mere negligence as insufficient to establish violation of due process); Whitley v. Albers, 475 U.S. 312 , 319 (1986) (same analysis for use of force during a prison riot); Baker v. McCollan, 443 U.S. 137, 144-46 (1979) (holding no fourth amendment violation occurred in the arrest of the wrong person on facially valid warrant); Paul, 424 U.S. at 709 (stating that stigmatizing actions by police are not actionable under the Constitution); see also Burnham, Separating Constitutional and Common Law Torts: A Critique and a Proposed Constitutional Theory of Duty, 73 MinN. L. Rev. 515, 515-16 (1989) (arguing that in the wake of Monroe, the Court has attempted unsuccessfully to separate those state torts that are properly remedied by $\S 1983$ from those requiring only a state common law remedy). 
jurisprudence has blunted the impact of $\S 1983$. Doctrines of standing, comity, and federalism have substantially restricted injunctive actions. ${ }^{11}$ Damage actions have been sharply curtailed by doctrines of qualified and absolute immunity, ${ }^{12}$ a redefinition of some constitutional deprivations, ${ }^{13}$ injection of notions of "culpability" beyond those normally imposed by tort law, ${ }^{14}$ and a back-door exhaustion requirement initiated by Parratt $v$. Taylor. ${ }^{15}$

This Article examines the doctrine of qualified immunity and its impact on the litigation of civil rights claims. Qualified immunity protects government officers from liability for money damages where the violated constitutional right was not "clearly established."16 If the defendant's conduct was "objectively reasonable"17 in light of

11 See, e.g., Lyons, 461 U.S. at 112 (stating that federal courts should exercise restraint in issuing injunctions against state police engaged in the administration of criminal laws); Simon v. Eastern Ky. Welfare Rights Org., 426 U.S. 26, 38 (1976) (suggesting that the relationship between the plaintiff and the alleged wrong, not the ultimate goal of the litigation, determines questions of standing); Rizzo v. Goode, 423 U.S. 362, 378 (1976) (stating that federal courts "must be constantly mindful" of federalism considerations); O'Shea v. Littleton, 414 U.S. 488, 493-94 (1974) (requiring the plaintiff in a $\S 1983$ action to allege an actual case or controversy); Younger, 401 U.S. at $42-43$ (outlining the long-standing public policy against federal court interference with state court proceedings).

12 See Anderson v. Creighton, 483 U.S. 635, 640-41 (1987) (holding federal agents not liable under $\$ 1983$ for warrantless searches if agents' conduct meets standard of objective legal reasonableness); Mitchell v. Forsyth, 472 U.S. 511,524 (1985) (finding that the Attorney General is entitled to qualified immunity as long as the challenged actions are not clearly violative of established constitutional or statutory rights); Harlow v. Fitzgerald, 457 U.S. 800, 807 (1982) (same, for state and federal executive officials); Butz v. Economou, 438 U.S. 478, 507-11 (1978) (recognizing the various degrees of immunity enjoyed by federal executive officials); Stump v. Sparkman, 435 U.S. 349, 356-57 (1978) (determining that judges enjoy absolute immunity when acting within their jurisdiction); Imbler v. Pachtman, 424 U.S. 409, 427-28 (1976) (holding prosecutors absolutely immune from § 1983 actions for prosecutorial functions).

13 See, e.g., Baker, 443 U.S. at 146 (holding that false imprisonment is not a constitutional violation under the fourteenth amendment "merely because the [arresting police officer] is a state official"); Paul, 424 U.S. at 711-12 (holding that defamation of character by local police does not constitute a deprivation of liberty or property and therefore does not invoke the protection afforded by $\S 1983$ ).

14 See, e.g., Whitley, 475 U.S. at 322 (describing the standard of culpability); Daniels, 474 U.S. at $332-33$ (stating that the requisite culpability must be greater than lack of due care to be actionable under $\$ 1983$ ).

$1545 \mathrm{I}$ U.S. 527 (1981), overruled in part, Daniels v. Williams, 474 U.S. 327 (1986). For a discussion of Parratt, see infra notes $49-58$ and accompanying text.

16 Harlow, 457 U.S. at 818.

17 Anderson v. Creighton, 483 U.S. 635, 640-41 (1987). Qualified immunity is not a defense to injunctive actions. See Prisco v. United States, 851 F.2d 93, 97 (3d Cir. 1988), cert. denied, 109 S. Ct. 2428 (1989); Hoohuli v. Ariyoshi, 74l F.2d 1169, 1175 (9th Cir. 1984). 
the existing legal principles governing the particular area, qualified immunity protects officials against damages.

Qualified immunity is a significant defense to $\S 1983$ actions. It directly limits individual liability for constitutional violations by denying a damage remedy for conduct that violates the Constitution. But qualified immunity is more than just another courthouse doorclosing device for limiting official accountability for unconstitutional conduct. As developed by the Court, the doctrine not only limits the remedial scope of $\S 1983$ and Bivens actions, ${ }^{18}$ but also poses the distinct danger of redefining substantive constitutional law. To understand the nature of the doctrine, its historical development, and its place in the larger context of civil rights jurisprudence, I return to Monroe v. Pape.

\section{General Overview: Monroe $v$. Pape And The Frankfurter DisSENT REvisited}

In Monroe v. Pape, ${ }^{19}$ the Court decided a fundamental issue of statutory construction regarding the scope of $\S 1983$. The Court

18 Section 1983 remedies violations committed under color of state law. There is no similar statute providing relief for the unconstitutional conduct of federal officials. In Bivens v. Six Known Unnamed Federal Agents, 403 U.S. 388 (1971), however, the Court authorized suit against federal officials directly under the fourth amendment. Bivens has been applied to violations of other constitutional protections. See, e.g., Carlson v. Green, 446 U.S. 14 (1980) (eighth amendment); Davis v. Passman, 442 U.S. 228 (1979) (fifth amendment, equal protection); Haynesworth v. Miller, 820 F.2d 1245 (D.C. Cir. 1987) (first amendment); United States Marine Lines, Inc. v. Schultz, 498 F.2d 1146 (4th Cir. 1974) (fifth amendment).

In recent years, the Court has refused to imply a cause of action where it has found "special factors counseling hesitation in the absence of affirmative action by Congress," Bivens, 403 U.S. at 396, or where Congress has provided an alternate remedy intended to be a substitute for recovery. See id. at 397. See, e.g., United States v. Stanley, 483 U.S. 669 (1987); Bush v. Lucas, 462 U.S. 367 (1983); Chappell v. Wallace, 462 U.S. 296 (1983).

The Court has also invoked a preemption doctrine to limit the relief available under 42 U.S.C. $\$ 1981$ (1982). In Jett v. Dallas Indep. School Dist., 109 S. Ct. 2702 (1989), the Court ruled that the express action at law provided by $\S 1983$ provides the exclusive federal damages remedy for claims made under $\$ 1981$ against a state actor. See id. at 2721-22.

19365 U.S. 167 (1961), overruled in part, Monell v. New York Dep't of Social Servs., 436 U.S. 658 (1978). The complaint alleged that thirteen Chicago police officers broke into the plaintiff's home without a warrant in the early hours of the morning. The officers awakened the Monroes, and forced them to stand naked in the living room while the officers searched the premises. Monroe then was taken into custody on "open" charges. He was held incommunicado for ten hours and interrogated regarding a murder committed two days earlier. Although a magistrate was available, Monroe was never taken before one. Subsequently, he was released and no charges were filed against him. See id. at 169. 
ruled that the phrase "under color of state law" was intended to include actions undertaken by government officials without state approval or authorization which were indeed contrary to established law, custom, and practice. ${ }^{20}$ Because the vast majority of civil rights violations are caused by officers or officials who act contrary not only to the Constitution, but to official policy, few violations would be remedied by a statute that reached only "official" deprivations. The officers in Monroe had no license under state law to enter the plaintiff's home without a warrant, assault the occupants, and destroy property in the course of an illegal search. In determining that $\S 1983$ was intended to remedy such violations, the Court freed the Act from a narrow and unjustified construction. ${ }^{21}$

The Court also ruled that $\S 1983$ did not require a showing of "specific intent" to violate a constitutional right. ${ }^{22}$ Distinguishing the criminal analogues to $\S 1983,{ }^{23}$ the Court held that traditional common law tort principles govern interpretation of $\S 1983:^{24}$ a government official is liable for the natural and probable consequences of her acts, regardless of whether she specifically manifests any particular level of culpability in connection with conduct that violates constitutional rights. ${ }^{25}$

Monroe confirmed that the Reconstruction Congress had intended to provide a federal cause of action coextensive with constitutional power in this field for violations of rights committed under color of state law. ${ }^{26}$ Home Telephone E Telegraph Co. v. City of Los Ange${ }^{l e s}{ }^{27}$ earlier had established that intentional conduct by state officials violative of the due process protections of the fourteenth amendment is actionable in federal court regardless of the existence of state remedies. Monroe held that the "under color of [state law]" element of $\S 1983$ includes conduct of state officers that transgresses state

20 See id. at 183-85.

21 See Monaghan, State Law Wrongs, State Law Remedies, and the Fourteenth Amendment, 86 Colum. L. Rev. 979 (1986); Shapo, Constitutional Tort: Monroe v. Pape and the Frontiers Beyond, 60 Nw. U.L. REv. 277 (1965); Developments in the Law - Section 1983 and Federalism, 90 HaRv. L. Rev. 1133 (1977).

22 See Monroe, 365 U.S. at 187.

23 See 18 U.S.C. $\$ \S 241,242$ (1982). These criminal statutes have been construed to require proof that the defendant acted with a "specific intent" to violate the victim's constitutional rights. See Screws v. United States, 325 U.S. 91, 103 (1945); United States v. Classic, 313 U.S. 299, 327 (1941).

24 See Monroe, 365 U.S. at 187.

25 See id.

26 See id. at $174-75$.

27227 U.S. 278 (1913). 
law; further, the statute's remedial provisions were "supplementary" to the state tort remedy. ${ }^{28}$

Justice Frankfurter alone dissented in Monroe. He agreed that no specific intent is required to prove a violation of $\S 1983,{ }^{29}$ but argued that $\S 1983$ was intended only to remedy deprivations of constitutional rights where the offending actions were authorized by state law. In his view, civil liability is "enforceable in the federal courts only in instances of injury for which redress was barred in the state courts because some [state law or custom] sanctioned the grievance complained of." 30 Thus, recourse to the federal courts is not necessary in "instances of acts [by state officials] in defiance of state law" because the state's authorities are capable of providing "effective and adequate reparation." 31

Justice Frankfurter conceded congressional power to provide a federal remedy for a state actor's unauthorized deprivation of due process rights, but asserted that the 1871 Congress had not done so. ${ }^{32}$ Significantly, Justice Frankfurter as a lone dissenter made the same policy arguments against expansion of $\S 1983$ that are made today by those who urge significant limits on the scope of this Act. ${ }^{33}$ $\mathrm{He}$ asserted that interference in local affairs would be substantial, and further:

Permitting such actions necessitates the immediate decision of federal constitutional issues despite the admitted availability of statelaw remedies which would avoid those issues. This would make inroads, throughout a large area, upon the principle of federal judicial self-limitation which has become a significant instrument in the efficient functioning of the national judiciary. ${ }^{34}$

28 See Monroe, 365 U.S. at 183.

29 See id. at 206-08 (Frankfurter, J., dissenting).

$30 \mathrm{Id}$. at 237 (Frankfurter, J., dissenting).

31 Id. at 236 (Frankfurter, J., dissenting).

32 See id. at 238-39 (Frankfurter, J., dissenting).

33 See, e.g., Pulliam v. Allen, 466 U.S. 522, 544, 554 (1984) (Powell, J., dissenting) (arguing that judicial liability for injunctive relief threatens judicial independence); Owen v. City of Independence, 445 U.S. 622, 658 (1980) (Powell, J., dissenting) (disagreeing with the Court's interpretation of $\$ 1983$ to impose "strict liability" on municipalities for constitutional violations); O'Connor, Trends in the Relationship Between the Federal and State Courts from the Perspective of a State Court Judge, 22 WM. \& MARY L. REv. 801, 808-10 (1981) (advocating exhaustion of state remedies as a prerequisite to bringing a $\$ 1983$ action); Whitman, Constitutional Torts, 79 MrcH. L. REv. 5, 70 (1980) (contending that individual claims for compensation pursuant to $\S 1983$ should be handled administratively in state systems subject to federal court scrutiny and correction).

34 Monroe, 365 U.S. at 240-41 (Frankfurter, J., dissenting). 
Justice Frankfurter's vision of $\S 1983$ was swept away by the 8-1 majority in Monroe and appeared interred by the doctrinal developments of the next fifteen years. ${ }^{35}$ As the number of cases brought under $\S 1983$ continued to grow, however, so did the arguments for finding some means of limiting access to the federal courts for what some viewed as "insignificant" or merely state law tort cases. ${ }^{36}$ In the absence of legislative change, the Supreme Court began to reconsider the basic doctrine affecting the construction of $\S 1983$, with an eye to limiting access to the federal courts by creating a structure capable of isolating those cases that presented only state common law tort claims. ${ }^{37}$ Without specific acknowledgment, the Court has turned to the Frankfurter vision of $\S 1983$ and has restricted $\S 1983$ remedies in many cases to misconduct that derives from express or implied authorization by the governmental unit or a policy-making official. ${ }^{38}$

Ironically, the Court's first articulation of this doctrine expanded the scope of $\S 1983$ liability. In Monell $v$. New York Department of Social Services, ${ }^{39}$ the Court overruled the part of Monroe that held that municipalities are not subject to suit under $\S 1983^{40}$ Based upon a fresh exposition of the legislative history of $\S 1983$, the Court ruled that municipalities were proper defendants in $\S 1983$ cases, but only where "the action that is alleged to be unconstitutional implements or executes" a municipal law, policy, or custom. ${ }^{41}$

Amenability of a municipality to suit carries important consequences. In appropriate cases, it focuses the litigation on the party directly responsible for the constitutional violation and thereby may provide a surer means of deterrence. ${ }^{42}$ Municipal liability also provides greater assurance that compensation in fact will be accom-

35 See supra text accompanying notes 3-8.

36 See, e.g., Parratt v. Taylor, 451 U.S. 527, 544 (1981) (finding that state's postdeprivation remedy satisfies requirements of due process), overruled in part, Daniels v. Williams, 474 U.S. 327 (1986); Paul v. Davis, 424 U.S. 693, 712 (1976) (holding that defamation by state actor does not establish a claim under $\$ 1983$ because no liberty or property rights were deprived).

37 See supra note 10.

38 See Blackmun, supra note 7, at 25.

39436 U.S. 658 (1978).

40 See id. at 663 .

41 Id. at 690.

42 Monell itself was a classic case of a municipal policy that caused the constitutional violation. At issue was an officially promulgated city policy that compelled pregnant employees to take unpaid leaves of absence before such leaves were medically necessary. See id. at 660-61. 
plished by placing the risk of loss on the population at large. ${ }^{43}$ This liability may also bring political pressures on the governing unit to change its unconstitutional policies or practices. ${ }^{44}$

Monell rejected vicarious liability for municipal defendants in cases where the liability is based solely on the employer-employee relationship and not on an official policy that violated an individual's constitutional right. ${ }^{45}$ The municipality is immune from suit if it did

43 Suits against individual defendants may be problematic. Individuals who commit the wrongs may not be identifiable or otherwise subject to service of process. Juries may be reluctant to assess a full measure of damages against relatively low paid civil servants, and even where they do, the defendants may be judgment proof. Further, individual defendants are entitled to defenses, such as qualified immunity, that are not available to governmental units. Given these considerations, some commentators have advocated a broadening of governmental liability. Professor Schuck argues that governmental liability best serves the purposes of $\S 1983$ and the Constitution, particularly because some officials may be risk-adverse, and therefore may not take appropriate action, all to the detriment of the general public. See P. Schuck, Suing Government 71-79 (1983); see also Bermann, Integrating Governmental and Officer Tort Liability, 77 Colum. L. REv. 1175, 1177-78 (1977) (praising the trend towards continued erosion of sovereign immunity that enhances the chances of recovery against government for torts committed by government agents); Newman, Suing the Lawbreakers: Proposals to Strengthen the Section 1983 Damage Remedy for Law Enforcers' Misconduct, 87 YALE L.J. 447, 455-58 (1978) (advocating a broadening of governmental liability).

The Court has stated that broad individual liability may prevent some persons from considering governmental employment and may render others risk-adverse, causing them to refrain from taking action in areas that would expose them to litigation. See Harlow v. Fitzgerald, 457 U.S. 800, 814 (1982); Butz v. Economou, 438 U.S. 478, 516-17 (1978); see also Mashaw, Civil Liability of Government Officers: Property Rights and Official Accountability, 42 LAW \& CoNTEMP. ProBs. 8, 26 (1978) (stating that the major explicit reason for insulating individuals from damage actions is the fear that damage exposure will induce timidity in executing duties). No empirical evidence has been presented to support these assertions. Indeed, there are studies to the contrary. See Jaron, The Threat of Personal Liability Under the Federal Civil Rights Act: Does It Interfere With the Performance of State and Local Government, 13 URB. Law. 1, 17-18 (1981) (asserting that limited data does not support fears of a trend toward successful suits when government officials are individually liable).

In restricting individual liability the Court has not provided significant alternative remedies. Of course, even governmental liability may not adequately deter or provide satisfactory compensation for the injured plaintiff. Civil rights plaintiffs are often burdened by disabling characteristics. Many have been suspects or defendants in the criminal justice system. They are often poor, members of racial or ethnic minority groups, without access to legal representation, and fearful of police retaliation. See Amsterdam, The Supreme Court and the Rights of Suspects in Criminal Cases, 45 N.Y.U. L. Rev. 785, 787 (1970); Foote, Tort Remedies for Police Violations of Individual Rights, 39 MINN. L. REv. 493, 500-08 (1955); Meltzer, Deterring Constitutional Violations By Law Enforcement Officials: Plaintiffs and Defendants as Private Attomeys General, 88 Colum. L. Rev. 247, 284 (1988).

44 See Owen v. City of Independence, 445 U.S. 622, 651-52 (1980); P. Schuck, supra note 43 , at $134-37$.

45 See Monell, 436 U.S. at 692. 
not "cause" an officer to subject someone to a tort. ${ }^{46}$ This limitation precludes municipal liability in a large number of cases. ${ }^{47}$ The limits of Monell are by no means certain, ${ }^{48}$ but the definitional line between authorized and unauthorized misconduct, which is virtually the same test Justice Frankfurter articulated for individual liability under $\S 1983$, is important for the purposes of this Article.

In Parratt v. Taylor, ${ }^{49}$ the Court addressed the issue from a different angle. A prisoner filed a $\S 1983$ action against state prison offcials who had negligently lost a hobby kit that had been mailed to him at the prison, and proceeded on the theory that officials acting under color of state law deprived him of property without due process of law. ${ }^{50}$ The Court agreed with the first two propositions, but ruled that there was no deprivation of due process of law because the state provided such process in the form of a post-taking remedy for the deprivation. ${ }^{51}$

Parratt has generated enormous controversy. ${ }^{52}$ The decision immediately calls into question a basic premise of Monroe: is the

\section{See id.}

47 See, e.g., City of Canton v. Harris, 109 S. Ct. 1197, 1204-05 (1989) (holding that unsatisfactory training of police officers constitutes insufficient grounds for holding city liable unless city exhibited deliberate indifference); City of St. Louis v. Praprotnik, 485 U.S. 112, 122 (1988) (stating that a municipality is liable only if the challenged action was pursuant to official law); Pembaur v. City of Cincinnati, 475 U.S. $469,483-84$ (1986) (determining that recovery from a municipality is limited to acts sanctioned by officials responsible for establishing municipal policy); City of Oklahoma City v. Tuttle, 471 U.S. 808, 824 (1985) (holding that municipal liability under $\S 1983$ can only be imposed for acts taken pursuant to unconstitutional municipal policy guidelines); see also Schnapper, Civil Rights Litigation After Monell, 79 Colum. L. Rev. 213, 266 (1979) (criticizing attempts to limit municipal liability).

48 See supra notes 45-47. In its most recent decision, the Court ruled that municipal liability based on a failure to train city employees could be imposed only where the city officials were deliberately indifferent to the rights of the injured person. See City of Canton, 109 S. Ct. at 1204-05; see also Jett v. Dallas Indep. School Dist., 109 S. Ct. 2702, 2723 (1989) (rejecting respondeat superior as a basis for municipal liability under $\$ 1983$ for violation of $\S 1981$ rights in recognition of Monell limitations).

49451 U.S. 527 (1981), overruled in part, Daniels v. Williams, 474 U.S. 327, 33031 (1986).

50 See id. at 538.

51 See id. at 541, 543-44.

52 See Blum, Applying the Parratt/Hudson Doctrine: Defining the Scope of the Logan Established State Procedure Exception and Determining the Adequacy of State Postdeprivation Remedies, 13 Hastings Const. L.Q. 695 (1986); Friedman, Parratt v. Taylor: Opening and Closing the Door on Section 1983, 9 HAstings Const. L.Q. 545 (1982); Monaghan, supra note 21; Moore, Parratt, Liberty, and the Devolution of Due Process: A Time for Reflection, 13 Wash. ST. U.L. Rev. 201 (1985); Neuman, Law Review Articles That Backfire, 21 U. Mich. J.L. REF. 697, 703-09 (1988); Whitman, Governmental Responsibility for Constitutional Torts, 85 MrCH. L. REv. 225, 265-76 (1986). 
existence of state remedies now relevant to the application of $\S 1983$ ? In Hudson v. Palmer, ${ }^{53}$ the Court ruled that intentional deprivations of due process are subject to the Parratt bar, ${ }^{54}$ but the Court has yet to define the exact boundaries of this doctrine. ${ }^{55}$ The lower federal courts have generally limited Parratt to due process claims, recognizing that the extension of the state remedy theory to substantive constitutional violations would directly contravene Monroe. ${ }^{56}$ As with Monell, however, the Parratt doctrine incorporates a clear limitation on its door-closing potential: the rule will be applied only in cases of "random" or "unauthorized" acts of governmental officials. ${ }^{57}$ Conceptually, the theory that postdeprivation state remedies are sufficient to provide due process is limited to situations where the state could not provide predeprivation process, where the tortious acts are not sanctioned by state policy or custom. ${ }^{58}$ Where the deprivation of liberty or property occurs as the result of a govern-

53468 U.S. 517 (1984).

54 See id. at 533.

55 See, e.g., Gregory v. Town of Pittsfield, 470 U.S. 1018, 1022-23 (1985) (O'Connor, J., dissenting from denial of certiorari) (arguing that postdeprivation remedies in state court may be inadequate); Logan v. Zimmerman Brush Co., 455 U.S. 422, 436-37 (1982) (holding that postdeprivation remedies do not satisfy due process where deprivation is caused by established state procedures); Monaghan, supra note 21, at 990-94 (explaining the ambiguities of Parratt). The Court has granted certiorari in a case which presents the question of whether Parratt bars a $\S 1983$ claim for intentional interference with a due process liberty interest. See Burch v. Apalachee Community Mental Health Servs., 840 F.2d 797 (1 lth Cir. 1988) (en banc), cert. granted sub nom. Zinermon v. Burch, 109 S. Ct. 1337 (1989).

56 See, e.g., Martin v. Dallas County, 822 F.2d 553, 555 (5th Cir. 1987) (fourth amendment claim based on false imprisonment); Smith v. City of Fontana, 818 F.2d 1411,1414 (9th Cir. 1987) (excessive force claim), cert. denied, 108 S. Ct. 311 (1987); Simmons v. Dickhaut, 804 F.2d 182, 185 (1st Cir. 1986) (right of access to courts); Mann v. City of Tuscon Dep't of Police, 782 F.2d 790, 792-93 (9th Cir. 1986) (per curiam) (holding that substantive constitutional claims are not barred by Parratt); Gilmere v. City of Atlanta, 774 F.2d 1495, 1500 (IIth Cir. 1985) (en banc) (distinguishing procedural and substantive due process claims), cert. denied, 476 U.S. 1115 (1986).

On the related issue of whether the violation of a due process liberty interest will implicate the Parratt rationale, the courts are divided. See, e.g., Conway v. Village of Mt. Kisco, 758 F.2d 46, 48 (2d Cir. 1985) (holding that there was no Parratt bar in a malicious prosecution claim), cert. granted in part sub nom. Cerbone v. Conway, 474 U.S. 110 , cert. dismissed as improvidently granted, 479 U.S. 84 (1986); Burch, 840 F.2d at 801 (recognizing a liberty violation claim under $\$ 1983$, but holding that Parratt does not apply to a violation of a liberty interest where the state had an opportunity to provide predeprivation process).

57 See Hudson, 468 U.S. at 532; Logan, 455 U.S. at 435-36.

58 See Parratt v. Taylor, 451 U.S. 527, 533-44 (1981), overruled in part, Daniels v. Williams, 474 U.S. 327, 330-31 (1986). 
mental policy or program, constitutional law both allows and requires predeprivation process. ${ }^{59}$

The issue of governmental authorization is also an integral factor in the constitutional calculus regarding standing in equitable actions under $\S 1983$. The Court has ruled that plaintiffs have standing in $\S 1983$ injunctive actions only where they can demonstrate a likelihood of future harm. ${ }^{60}$ In City of Los Angeles v. Lyons, ${ }^{61}$ the Court refused to grant injunctive relief to a plaintiff who had suffered permanent physical injuries when a police officer administered a "chokehold" in effecting an arrest, even though the record demonstrated that this police practice was commonly used in circumstances not justifying such force. ${ }^{62}$ The practice had caused sixteen deaths during a period of several years. ${ }^{63}$ The Court determined that the past injury had no continuing effects sufficient to provide standing for prospective relief and that the plaintiff was unable to show that he, as opposed to any other citizen, would again suffer the same unconstitutional conduct. ${ }^{64}$ Of particular significance to the Court was Lyons' failure to show that the chokehold was authorized by city policy. ${ }^{65}$ The Court viewed the use of the chokehold in the circumstances of the particular case, in which the plaintiff alleged no provocation or resistance on his part, as aberrational and unauthorized. ${ }^{66}$ Equitable relief was justified only if "the City ordered or authorized police officers to act in such manner." 67

Parratt, Lyons, and Monell expressly condition liability under

59 See, e.g., Cleveland Bd. of Educ. v. Loudermill, 470 U.S. 532, 547-48 (1985) (holding that a pretermination hearing is required); Lee v. Hutson, 810 F.2d 1030 (11th Cir. 1987) (state appeal process was adequate remedy for review of employment termination).

60 See City of Los Angeles v. Lyons, 461 U.S. 95, 101-05 (1983); O'Shea v. Littleton, 414 U.S. $488,496-97$ (1974).

61461 U.S. 95 (1983).

62 See id. at $110-13$.

63 See id. at 115-16 (Marshall, J., dissenting).

64 See id. at 101-05.

65 See id. at 106.

66 See id. at 107-08.

67 Id. at 106. Lyons has been the subject of severe criticism. See, e.g., Cole, Obtaining Standing to Seek Equitable Relief: Taming Lyons, in CiviL Rights Litigation and AtToRney Fees AnNual Handbook 101 (J. Lobel ed. 1986) (arguing that Lyons should be construed narrowly to limit its potentially illegitimate reach); Fallon, of Justiciability, Remedies, and Public Law Litigation: Noles on the Jurisprudence of Lyons, 59 N.Y.U. L. REv. 1 (1984) (arguing that the Court's use of the doctrines of standing and equitable restraint to restrict public law litigation is flawed). The doctrinal flaws discussed in these articles are not the only problems with Lyons; the opinion reflects a startling lack of sensitivity to the fatal consequences of the police practice. 
$\S 1983$ on the factor of governmental authorization. As such, they run counter to Monroe's construction of $\S 1983.68$ At the same time, the Court has broadened the defense of qualified immunity in a manner inconsistent with other important aspects of Monroe. The Court's most recent decisions in this area raise troublesome questions concerning the scope of remedies in constitutional tort litigation.

\section{The Historical Development Of The Immunity Shield}

Immunity doctrine implicates constitutional, statutory, and common law considerations. State immunity is controlled by the eleventh amendment, ${ }^{69}$ presidential immunity by constitutional principles of separation of powers, ${ }^{70}$ municipal immunity by statutory interprétation, ${ }^{71}$ and individual immunity by a combination of statutory, common law, and policy considerations. ${ }^{72}$

The availability of immunities for individual defendants has revolved around two central questions: (1) which officials are entitled to an absolute immunity from suit for constitutional torts, and (2) what circumstances entitle officials who are not provided absolute immunity to a qualified immunity from suit? ${ }^{73}$ Qualified immunity

68 See supra text accompanying notes 19-25.

69 See, e.g., Edelman v. Jordan, 415 U.S. 651, 677 (1974) (holding that the eleventh amendment bars the award of damages against a state, but permits prospective injunctive relief), remanded sub nom. Jordan v. Trainor, 405 F. Supp. 802 (N.D. Ill. 1975), rev'd, 551 F.2d 152 (7th Cir. 1977), affd sub nom. Quern v. Jordan, 440 U.S. 332 (1979); Jackson, The Supreme Court, The Eleventh Amendment, and State Sovereign Immunity, 98 YALE L.J. 1, 3 (1988) (stating that the eleventh amendment "has been construed to embody or recognize a broad constitutional immunity for states from being sued in federal courts").

70 See Nixon v. Fitzgerald, 457 U.S. 731, 748-54 (1982).

71 See, e.g., City of Canton v. Harris, 109 S. Ct. 1197, 1206 (1989) (recognizing that a municipality's failure to train its employees can be the basis for liability under $\S 1983$, but only where the failure is "closely related to the ultimate injury" and "reflects deliberate indifference to the constitutional rights of its inhabitants"); City of Oklahoma City v. Tuttle, 471 U.S. 808, 823 (1985) (limiting the Monell standard for establishing municipal liability under $\S 1983$ by requiring an "affirmative link between the policy and the particular constitutional violation alleged"); Monell v. New York Dep't of Social Servs., 436 U.S. 658, 694 (1978) (construing $§ 1983$ to impose municipal liability where the city's "policy or custom" is the "moving force of the constitutional violation").

72 See, e.g., Anderson v. Creighton, 483 U.S. 635, 645 (1987) (reaffirming the principle of qualified immunity as established in Harlow); Harlow v. Fitzgerald, 457 U.S. 800, 806-07, 818 (1982) (granting qualified immunity to "government officials performing discretionary functions . . . insofar as their conduct does not violate clearly established statutory or constitutional rights of which a reasonable person would have known").

73 The doctrine of absolute immunity raises issues largely beyond the scope of this Article. Certain officials have received absolute immunity from suit for damages 
has emerged as one of the most significant and problematic defenses to claims of civil rights violations. Its development in the Supreme Court has been marked by ad hoc decisionmaking, conflicting rationales, and a high degree of doctrinal manipulation. Today, it stands as a legal principle defined primarily by the Court's own policy judgment that an individual's right to compensation for constitutional violations and the deterrence of unconstitutional conduct should be subordinated to the governmental interest in effective and vigorous execution of governmental policies and programs.

Given the broad barriers to damage actions erected by the Court in its construction of the immunity doctrine, one would expect strong constitutional or statutory support for such a defense. The Constitution, however, provides no basis for qualified immunity, ${ }^{74}$ and, on its face, the language of $\S 1983$ "admits of no immunities."75

In Tenney $v$. Brandhove, ${ }^{76}$ the Court stated that the common law of 1871 should govern interpretation of $\S 1983 .{ }^{77}$ The Court has reaffirmed this position in a number of cases, ${ }^{78}$ including Monroe $v$. Pape $^{79}$ Because the Court views only immunities recognized at common law in 1871 as read into $\S 1983,,^{80}$ and allows no immunities that would be inconsistent with the purposes of $\S 1983$ at all, ${ }^{81}$ the threshold question is whether and to what degree qualified immunity would have been a defense in common law analogues to constitutional tort claims. ${ }^{82}$

resulting from acts within the scope of their duties. See, e.g., Nixon, 457 U.S. at 748-54 (presidential immunity for executive acts); Stump v. Sparkman, 435 U.S. 349 (1978) (judicial immunity for judicial acts); Imbler v. Pachtman, 424 U.S. 409 (1976) (prosecutorial immunity for acts connected to prosecutorial functions); Tenney v. Brandhove, 341 U.S. 367 (1951) (legislative immunity for acts in legislative capacity).

74 See Butz v. Economou, 438 U.S. 478, 497 (1978); see also Comment, Accountability for Government Misconduct: Limiting Qualified Immunity and the Good Faith Defense, 49 TEmP. L.Q. 938, 939-40 (1976) (stating that official immunity is a judicially created doctrine that must be subjected to careful scrutiny).

75 Imbler, 424 U.S. at 417.

76341 U.S. 367 (1951).

77 See id. at 379.

78 See, e.g., Imbler, 424 U.S. at 421 (stating that the problem of prosecutor's liability is based on common law immunity issues).

79365 U.S. 167 (1961) (tracing and applying the original interpretation of $\S 1983)$, overruled in part, Monell v. New York Dep't of Social Servs., 436 U.S. 658 (1978).

80 See Imbler, 424 U.S. at 417-24; see also Owen v. City of Independence, 445 U.S. 622,638 (1980) (stating that the statute incorporates the immunity only if that immunity "was well established at common law at the time $\S 1983$ was enacted").

81 See, e.g., Tower v. Glover, 467 U.S. 914, 922-23 (1984) (holding that state public defenders are not immune from liability under $\$ 1983$ ).

82 See, e.g., City of Newport v. Fact Concerts, Inc., 453 U.S. 247, 258-59 (1981) 
The relevant "background of tort liability" 83 provided a very narrow immunity for defendant officials, at least in the fourth amendment area. In Director General v. Kastenbaum, ${ }^{84}$ the Court ruled:

The gist of it is an unlawful detention, and that being shown the burden is on the defendant to establish probable cause for the arrest. The want of probable cause, certainly in the absence of proof of guilt or conviction of the plaintiff, is measured by the state of the defendant's knowledge, not by his intent. It means the absence of probable cause known to the defendant when he instituted the suit. But the standard applied to the defendant's consciousness is external to it. The question is not whether he thought the facts to constitute probable cause, but whether the court thinks they did. Holmes on the Common Law, 140. Probable cause is a mixed question of law and fact. The court submits the evidence of it to the jury, with instructions as to what facts will amount to probable cause if proved .... But, as we have seen, good faith is not enough to constitute probable cause. That faith must be grounded on facts within knowledge of the [arresting officer], which in the judgment of the court would make his faith reasonable. ${ }^{85}$

In Pierson v. Ray, ${ }^{86}$ the defendant police officers arrested the plaintiffs pursuant to a state statute later ruled unconstitutional because it was used to enforce segregation of interstate transportation facilities. ${ }^{87}$ The Court ruled that the officers were entitled to a qualified immunity from damages liability if they had probable cause

(stating that only after consideration "of both history and policy has the Court construed $\S 1983$ " to include the immunity defense). In Jones v. Preuit \& Mauldin, 851 F.2d 1321 (11th Cir. 1988), vacated, 109 S. Ct. 1105 (1989), Judge Tjoflat suggested in his concurrence that the courts have the inherent power to modify remedies that are judicially created under the Bivens doctrine in order to vindicate the constitutional wrong alleged, and that qualified immunity would be an appropriate judicially recognized defense. See id. at 1332-35 (Tjoflat, J., concurring). However that may be, qualified immunity was first applied in a $\S 1983$ case, see Pierson v. Ray, 386 U.S. 547 (1967), modified, Harlow v. Fitzgerald, 457 U.S. 800 (1982), thus precluding an immunity theory based on a court's inherent power to craft its own defenses where it has implied a cause of action. See Gildin, Immunizing Intentional I'iolations of Constitutional Rights Through Judicial Legislation: The Extension of Harlow v. Fitzgerald to Section 1983 Actions, 38 EMORY L.J. 369 (1989) (arguing that the Court incorrectly applied Harlow immunity principles to $\S 1983$ cases); Matasar, Personal Immunities Under Section 1983: The Limits of the Court's Historical Analysis, 40 ARK. L. Rev. 741 (1987) (questioning the Court's view of the extent to which immunities were available to government officials at common law).

83 Monroe, 365 U.S. at 187.

84263 U.S. 25 (1923).

85 Id. at 27-28 (emphasis added).

86386 U.S. 547 (1967), modified, Harlow v. Fitzgerald, 457 U.S. 800 (1982).

87 See id. at 549, 557. 
for the arrests and if they acted in good faith to prevent violence and not to punish blacks for using the white waiting rooms. ${ }^{88}$ The Court thereby recognized one narrow exception for special treatment: an officer is immune if she acts in good faith and is authorized by a state statute that subsequently is declared unconstitutional. ${ }^{89}$

Although Pierson showed fidelity to common law principles, the Court soon abandoned the common law as the controlling source of immunity. In short order the Court rejected the limits of the common law and, invoking considerations of "public policy," substituted its own policy judgments for the commands of both $\S 1983$ and the Constitution. ${ }^{90}$

The most recent statement of the controlling standard in Anderson $v$. Creighton ${ }^{91}$ provides immunity to a fourth amendment claim where the legal principle upon which the claim is based is not clearly

88 See id. at 557.

89 This narrow exception to liability was recognized at common law. See Restatement (SECOND) of ToRTs $\$ 121$ comment i (1965).

A peace officer making an arrest without a warrant is protected in every case where he acts under a reasonable mistake as to the existence of facts which, under the rule stated in this Section, justify an arrest without a warrant. On the other hand, no protection is given to a peace officer who, however reasonably, acts under a mistake of law other than a mistake as to the validity of a statute or ordinance. Thus, an officer is not privileged to arrest another whom he reasonably suspects of having committed an act which the officer, through a mistake of law reasonable in one of his position, believes to be a common law felony. So too, a peace officer is not privileged to arrest another whom he reasonably suspects of having committed an act which the officer, through a mistaken construction of a statute, believes to have been made a felony by such statute. And this is true although the reasonable character of the officer's mistake is proved by the fact that at the time of the arrest the statute is generally understood to make such an act a felony and is not judicially construed to the contrary until after the arrest is made.

Id.; see also Theis, "Good Faith" as a Defense to Suits for Police Deprivations of Individual Rights, 59 MinN. L. REV. 991, 991-97 (1975) (arguing that mistake of law affords no immunity to the officer and that her actions can be justified only by objective standards of the common law).

90 See Anderson v. Creighton, 483 U.S. 635, 645 (1987) (stating that Harlow "completely reformulated qualified immunity along principles not at all embodied in the common law" and that "we have never suggested that the precise contours of official immunity can and should be slavishly derived from the often arcane rules of the common law"). Just three years earlier, the Court had stated that it did "not have a license to establish immunities from $\$ 1983$ actions in the interests of . . sound public policy." Tower v. Glover, 467 U.S. 914, 922-23 (1984). The Court ruled that it was for Congress to determine whether actions under $\$ 1983$ have "become too burdensome to state of federal institutions and, if so, what remedial action is appropriate." Id. at 923 .

ol 483 U.S. 635 (1987). 
established or, even if the legal standard is clearly established (in this case the probable cause requirement of the fourth amendment), if a reasonable police officer would have believed the conduct to be legal. ${ }^{92}$ Furthermore, subjective bad faith or malice may not defeat the immunity claim. ${ }^{93}$ Each element of the Pierson test is therefore negated: the officer need not have probable cause and she need not have acted in good faith. How did the Court get from Monroe and Pierson to Anderson? An analysis of the Court's qualified immunity opinions shows an overriding concern with protecting public officers from damages liability. In addition, the Court has responded to the conceptual difficulties inherent in a process that seeks to construct a unitary doctrine, applicable to a wide range of officials and to the entire spectrum of constitutional violations, by redefining the substantive definition of qualified immunity wherever existing doctrine would limit the defense.

The Court's first considered analysis of qualified immunity involved the claim of Ohio's Governor and other high state officials that they were entitled to "absolute 'executive immunity." "94 The $\S 1983$ suit for damages arose from the killing of three students at Kent State by the Ohio National Guard. ${ }^{95}$ The Court rejected the absolute immunity defense, but ruled that the defendants could assert a defense of qualified immunity: "a qualified immunity is available to officers of the executive branch of government, the variation being dependent upon the scope of discretion and responsibilities of the office and all the circumstances as they reasonably appeared at the time of the action on which liability is sought to be based."96

The Court relied on Pierson and common law principles in determining that qualified immunity was available. ${ }^{97}$ The standard adopted required the officer to demonstrate both a reasonable (objective) basis for her actions, and a "good faith belief" in the lawfulness of the acts. ${ }^{98}$ In the absence of a factual record, the Court spoke only in general terms, and provided little guidance regarding the specific application of the defense to executive officials. The decision made it clear that both objective reasonableness and subjec-

92 See id. at 639-41.

93 See id. at 641, 646.

94 Scheuer v. Rhodes, 416 U.S. 232, 238 (1974), modified, Harlow v. Fitzgerald, 457 U.S. 800 (1982).

95 See id. at 234.

96 Id. at 247.

97 See id. at 244-45.

98 See id. at 247-48. 
tive good faith were elements of the defense, and that in defending against claims of improper deployment and use of force, the state officials would have to demonstrate the "good faith" of their actions. ${ }^{99}$

Qualified immunity was addressed next in Wood v. Strickland. ${ }^{100}$ The defendants were local school board officials who were sued for violating the procedural due process rights of students in expulsion proceedings. The Court relied upon common law principles and "strong public-policy" 101 considerations in stating the following test for qualified immunity:

[A] school board member is not immune from liability for damages under $\S 1983$ if he knew or reasonably should have known that the action he took within his sphere of official responsibility would violate the constitutional rights of the student affected, or if he took the action with the malicious intention to cause a deprivation of constitutional rights or other injury to the student. ${ }^{102}$

The Court subsequently applied the Wood test to prison officials, ${ }^{103}$ mental hospital administrators, ${ }^{104}$ and federal cabinet level officers. ${ }^{105}$ The Court made it clear that the doctrine incorporated an objective element of reasonableness ${ }^{106}$ and a subjective element of malice. ${ }^{107}$

Wood provided a more than marginal increase in the scope of the immunity. Pierson concerned an officer acting pursuant to a presumptively valid statute, which only later was declared unconstitutional. The unfairness of holding the officer liable was readily apparent. Wood extended this protection to an official who in good faith took certain discretionary action, but did not reasonably know, nor reasonably should have known, of its illegality. ${ }^{108}$ The Court's

99 See id. at 245-48.

100420 U.S. 308 (1975), modified, Harlow v. Fitzgerald, 457 U.S. 800, 815-19 (1982).

101 Id. at 318 .

102 Id. at 322.

103 See Procunier v. Navarette, 434 U.S. 555, 562-66 (1978), modified, Harlow v. Fitzgerald, 457 U.S. 800 (1982).

104 See O'Connor v. Donaldson, 422 U.S. 563 (1975), modified, Harlow v. Fitzgerald, 457 U.S. 800 (1982).

105 See Butz v. Economou, 438 U.S. 478 (1978).

106 See Wood, 420 U.S. at 322 (stating that an official is not immune "if he knew or reasonably should have known that the action ... would violate ... constitutional rights").

107 See id. (stating that an official is not immune "if he took the action with the malicious intention to cause a deprivation of constitutional rights or other injury"). 108 See id. 
primary concern appeared to be protection of the official who acts in an area where unsettled laws prevent the reasonable knowledge of the constitutional protections.

In Procunier v. Navarette, ${ }^{109}$ the Court discussed the qualified immunity doctrine in the context of a prisoner's claim that officials had violated his first amendment rights by negligently interfering with his outgoing mail. The prison officials claimed that at the time of the incident in question there was no established first amendment right protecting the outgoing mailing privileges of state prisoners. ${ }^{110}$ First amendment jurisprudence gave strong grounds for the prisoner's claim, but no case had expressly so ruled at the time of the incident. ${ }^{11}$ The Court ruled that officials lose the immunity "if the constitutional right allegedly infringed by them was clearly established at the time of their challenged conduct, if they knew or should have known of that right and if they knew or should have know that their conduct violated the constitutional norm."112 The Court's ruling expanded the immunity defense by keying the question of whether an official knew or reasonably should have known of the right to a determination of whether the right had been "clearly established." 113 Of course, whether one "knew or reasonably should have known"114 that the action was unconstitutional or whether a principle was "clearly established" are questions that invite a broad range of answers, and the lower federal courts did not provide consistent interpretations. ${ }^{15}$ Furthermore, both prongs of

109434 U.S. 555 (1978), modified, Harlow v. Fitzgerald, 457 U.S. 800 (1982).

110 See id. at 562-63.

111 See, e.g., Wilkinison v. Skinner, 462 F.2d 670, 672-73 (2d Cir. 1972) (presuming that only a "clear and present danger" to prison discipline or security would justify interference with prisoner's correspondence); Brown v. Peyton, 437 F.2d 1228, 1230-31 (4th Cir. 1971) (noting that "a prisoner does not shed his first amendment rights at the prison portals," although such rights may be restricted); Jackson v. Godwin, 400 F.2d 529, 540-42 (5th Cir. 1968) (holding that censorship of prisoner mail cannot be arbitrary and must further a compelling state interest); Martinez v. Procunier, 354 F. Supp. 1092, 1097 (N.D. Cal. 1973) (three-judge panel holding that first amendment protects prisoners' rights to correspond), affd on narrower grounds, 416 U.S. 396, 413 (1974) (holding that the first amendment rights of the addressees of a prisoner's correspondence were violated when officials interfered with the prisoner's outgoing mail).

112 Navaretle, 434 U.S. at 562.

113 Id. at 565 . In dissent, Justice Stevens agreed that all state executive officials should be entitled to qualified immunity, but he was critical of the broad definition of "good faith." See id. at 569-74 (Stevens, J., dissenting). Justice Stevens noted that the Court had abandoned the common law as the source of immunity doctrine. See id. at 568 (Stevens, J., dissenting).

11.4 Id. at 562 (quoting Wood, 420 U.S. at 322).

115. See, e.g., Clanton v. Orleans Parish School Bd., 649 F.2d 1084, 1100-1101 
the test invited extensive pre-trial discovery and complex trial litigation. In determining the objective reasonableness of the actions, some inquiry was necessary into the established practices, policies, and customs of the institution from which the defendant official derived her authority and direction. Training, supervision, and standards of operation were all relevant. ${ }^{116}$

The issue of good faith required even more extensive discovery into the official's subjective frame of mind ${ }^{117}$ including questions of malice, intent, and bias. ${ }^{18}$ As a result, few cases could be resolved on summary judgment. ${ }^{119}$ At trial, the jury had to sift through these difficult questions in determining liability.

In Harlow $v$. Fitzgerald, ${ }^{120}$ the Court reconsidered and radically reformulated the immunity doctrine. Harlow was a suit by a federal government whistle-blower who alleged first amendment violations against several White House aides and other high ranking government officials. Butz $v$. Economou ${ }^{121}$ had previously denied even high level federal officials absolute immunity, but had made clear that federal executive officials are entitled to a limited immunity to protect against good faith "mistakes in judgment, whether the mistake is one

(5th Cir. 1981) (noting that due process and equal protection principles for teacher's maternity leaves are not clearly established); Chavis v. Rowe, 643 F.2d 1281, 1288-89 (7th Cir.) (stating that due process principles for disciplinary action of prisoners have been partially established), cert. denied, 454 U.S. 907 (1981); Little v. Walker, 552 F.2d $193,197-98$ (7th Cir. 1977) (holding that the cruel and unusual punishment principle for segregation of prisoners is clearly established), cert. denied, 435 U.S. 932 (1978); Slate v. McFetridge, 484 F.2d 1169 (7th Cir. 1973) (finding that due process principles governing the granting of city park permits for political rallies are established). See generally S. NAHMOD, Civil Rights and Civil Liberties Litigation: THE LAw OF SECTION 1983, §8.03, at 455-57 (2d ed. 1986) (analogizing the vagueness inherent in the objective prong of the qualified immunity test to the vagueness of the reasonable man standard in negligence cases).

116 See Wood v. Strickland, 420 U.S. 308, 318 (1975) (noting that the breadth of qualified immunity available to an official is "dependant upon the scope of discretion and responsibilities of the office and all the circumstances as they reasonably appeared at the time of the action" (quoting Scheuer v. Rhodes, 416 U.S. 232, 247$48(1974))$ ).

117 See Harlow v. Fitzgerald, 457 U.S. 800, 816-17 (1982).

118 See Friedman, The Good Faith Defense in Constitutional Litigation, 5 Hofstra L. REv. 501, $511-12$ (1977).

119 See, e.g., Landrum v. Moats, 576 F.2d 1320, 1329 (8th Cir.) ("Because good faith is dependent on motivation and conduct of the defendant as established at trial, the validity of the defense is ordinarily a question for the jury."), cert. denied, 439 U.S. 912 (1978); Duchesne v. Sugarman, 566 F.2d 817, 832-33 (2d Cir. 1977) ("[T]he issue of good faith present[s] questions of fact which are peculiarly within the jury's province.").

120457 U.S. 800 (1982).

121438 U.S. 478 (1978). 
of fact or one of law." 122 There was a "need to protect officials who are required to exercise their discretion and the related public interest in encouraging the vigorous exercise of official authority." 123

In Harlow, Justice Powell recognized the need for an action in damages for violations of rights, but gave greater weight to the claim of government officials that such suits

frequently run against the innocent as well as the guilty-at a cost not only to the defendant officials, but to society as a whole. These social costs include the expenses of litigation, the diversion of official energy from pressing public issues, and the deterrence of able citizens from acceptance of public office. Finally, there is the danger that fear of being sued will "dampen the ardor of all but the most resolute, or the most irresponsible [public officials], in the unflinching discharge of their duties." 124

Because the subjective prong required discovery into the state of mind of the official, it had the potential to disrupt the smooth and efficient flow of government. According to the Court, the subjective test allowed otherwise meritless claims to survive a motion for summary judgment because the inquiry into an official's subjective state of mind was considered a question of fact that should always go to the jury. ${ }^{125}$ To this end, the majority struck down the subjective element of the good faith immunity doctrine in favor of an "objective" standard: "[w]e therefore hold that government officials . . generally are shielded from liability for civil damages insofar as their conduct does not violate clearly established statutory or constitutional rights of which a reasonable person would have known."126

The Court stressed that the essential issue for determination was whether the defendant had acted with objective reasonableness, measured by clearly established law. ${ }^{127}$ Because the standard was purely legal, the Court stressed that it should be decided prior to discovery:

On summary judgment, the judge appropriately may determine, not only the currently applicable law, but whether that law was clearly established at the time an action occurred. If the law at that time was not clearly established, an official could not reasonably be

122 Id. at 507.

123 Id. at 506.

124 Harlow, 457 U.S. at 814 (footnote omitted) (quoting Gregorie v. Biddle, 177 F.2d 579, 581 (2d Cir. 1949), cert. denied, 339 U.S. 949 (1950)).

125 See id. at 815-16.

$126 \mathrm{Id}$. at 818.

127 See id. at 819. 
expected to anticipate subsequent legal developments, nor could he fairly be said to "know" that the law forbade conduct not previously identified as unlawful. Until this threshold immunity question is resolved, discovery should not be allowed. If the law was clearly established, the immunity defense ordinarily should fail, since a reasonably competent public official should know the law governing his conduct. ${ }^{128}$

In short order, the Court decided two more qualified immunity cases that presented the issue of what is meant by "clearly established law." The Court's rulings reflected a broad reading of Harlow immunity. In Davis $v$. Scherer, ${ }^{129}$ a state highway patrolman was dismissed from his position without a pretermination hearing. The plaintiff argued that he had a clearly established due process right to a pretermination hearing under Board of Regents $v$. Roth ${ }^{130}$ and its progeny. The Court sustained the qualified immunity defense, ruling that as of the date of the termination, under the controlling precedent in the circuit, there was no constitutional right for a pretermination hearing for a civil service employee. ${ }^{131}$ The plaintiff had been provided some notice and opportunity to respond, which was held to satisfy whatever constitutional requirements existed at the time. ${ }^{132}$

In Mitchell $v$. Forsyth, ${ }^{133}$ the Court sustained a qualified immunity claim by former Attorney General John Mitchell with respect to his authorization in 1970 and 1971 of warrantless "national security" electronic surveillance. At the time Mitchell authorized these surveillances, the Supreme Court had not yet specifically ruled on the issue of whether a claim of national security could exempt electronic surveillances from the fourth amendment warrant procedure. ${ }^{134}$ The plaintiff argued that the fourth amendment cases clearly estab-

128 Id. at 818-19 (footnote omitted).

129468 U.S. 183 (1984).

130408 U.S. $564,569-70$ (1972). Roth required "some kind of prior hearing" to satisfy due process upon termination, but only when a liberty or property interest is threatened. Id.

131 See Davis, 468 U.S. at 192-93.

132 The plaintiff had claimed that state regulations required greater procedural safeguards and, therefore, were relevant to the determination of whether the defendant should have known of the existence of the due process right. The Court rejected this assertion, stating that it related only to the now irrelevant issue of subjective good faith and that state laws were not a proper source for determining whether or not a constitutional right was clearly established. See id. at 193-94 \& n.12.

133472 U.S. 511 (1985).

134 The plaintiff learned of the wiretap as a result of a disclosure at an unrelated criminal prosecution. See id. at 513-14. Shortly thereafter, the Court held that the fourth amendment prohibited "the use of warrantless wiretaps in cases involving 
lished that all searches and seizures (including electronic surveillances) must have prior judicial approval, except in limited, specifically designated circumstances. ${ }^{135}$ Because the government was seeking to establish a new exception to the warrant requirement, it could not credibly claim that the fourth amendment warrant procedure was not clearly established. ${ }^{136}$

The Court rejected this analysis, pointing to Katz $v$. United States, ${ }^{137}$ which expressly left open the issue of the constitutionality of warrantless national security electronic surveillance. ${ }^{138}$ Thus, Davis and Forsyth made clear that something more than the existence of general legal principles (the due process right to a pretermination hearing or fourth amendment prohibition against warrantless searches) was necessary to show that the controlling legal doctrine was "clearly established." 139

Meanwhile, in the lower courts, the application of this standard proved to be anything but routine, and a welter of confusing and conflicting opinions has emerged over the proper definition of "clearly established." 140 One line of cases requires officials to follow general, well-developed constitutional doctrine, even where the facts

domestic threats to the national security." Id. at 515 (citing United States v. United States District Court, 407 U.S. 297, 320-21 (1972)).

135 See id. at 515.

136 See id. at 517.

137389 U.S. 347 (1967).

138 See Forsyth, 472 U.S. at 531 (citing Katz, 389 U.S. at 358 n.23).

139 In Malley v. Briggs, 475 U.S. 335, 343-44 (1986), the Court ruled than an officer is entitled to qualified immunity where he conducts a search or arrest in reliance on a warrant that fails to state probable cause if a reasonably well-trained officer would have believed that the warrant was constitutionally sufficient.

140 See, e.g., Jones v. Preuit \& Mauldin, 822 F.2d 998, 1005 (11th Cir. 1987) (holding that procedural safeguards in the attachment of property are clearly established), affd en banc, 851 F.2d 1321 (11th Cir. 1988), vacaled, 109 S. Ct. 1105 (1989); Robison v. Via, 821 F.2d 913, 921, 923 (2d Cir. 1987) (holding that the seizure of children for investigating abuse reports is not clearly established as a violation, but the use of excessive force limit is clearly established); Colaizzi v. Walker, 812 F.2d 304, 307-10 (7th Cir. 1987) (finding that the governor's public comments about state employees in conjunction with their firing is not a clearly established violation); Floyd v. Farrell, 765 F.2d 1, 5-6 (Ist Cir. 1985) (finding an arrest based on reasonably held but erroneous belief in probable cause is not established clearly as a violation); People of Three Mile Island v. Nuclear Regulatory Comm'rs, 747 F.2d 139, 145-48 (3d Cir. 1984) (holding that the release of radioactive gas without a prior hearing is not a clearly established violation); Whisenant v. Yuam, 739 F.2d 160, 165 (4th Cir. 1984) (holding that the necessity of medical treatment for prisoners is clearly established), abrogated on other grounds, Mallard v. United States District Court, 109 S. Ct. 1814 (1989); Fujiwara v. Clark, 703 F.2d 357, 361-62 (9th Cir. 1983) (finding constitutional violations in the firing of state employees clearly established). 
at issue had not previously been the subject of constitutional adjudication. In People of Three Mile Island v. Nuclear Regulatory Commissioners, ${ }^{141}$ for example, the court adopted a flexible view of what constitutes an established right by "requiring some but not precise factual correspondence [with precedents] and demanding that officials apply general, well developed legal principles." ${ }^{42}$ In Hobson $v$. Wilson, ${ }^{143}$ the court ruled that certain counter-intelligence actions taken by FBI agents against black political activists violated clearly established first amendment rights, even though the exact conduct of the agents had never been proscribed. The court set forth the following understanding of Harlow:

[T]he right at issue can be defined neither so broadly as to parrot the language in the Bill of Rights, nor so narrowly as to require that there be no distinguishing facts between the instant case and existing precedent. The former reading of Harlow would, of course, undermine the premise of qualified immunity that the Government actors reasonably should know that their conduct is problematic. The latter reading, on the other hand, would unquestionably turn qualified into absolute immunity by requiring immunity in any new fact situation. ${ }^{144}$

Other courts require plaintiffs to show a significantly higher correlation between the established constitutional principle and the right asserted in the new case. These courts have sustained immunity defenses in the absence of fact-specific precedent. ${ }^{145}$ There is

141747 F.2d 139 (3d Cir. 1984).

142 Id. at 144 .

143737 F.2d 1, 29 (D.C. Cir. 1984), cert. denied, 470 U.S. 1084 (1985).

144 Id. at 26.

145 See, e.g., Krause v. Penny, 837 F.2d 595, 596-97 (2d Cir. 1988) (noting the lack of fact-specific precedent to extend fourth amendment protection against a warrantless arrest in a driveway); Dominque v. Telb, 831 F.2d 673, 676-77 (6th Cir. 1987) (holding that the plaintiff in a $\$ 1983$ action must include all necessary factual allegations in the original complaint); Powers v. Lightner, 820 F.2d 818, 821 ( 7 th Cir. 1987) (granting qualified immunity in the absence of analogous authority holding unconstitutional the acts of FBI agents), cerl. denied, 108 S. Ct. 1057 (1988); Colaizzi v. Walker, 812 F.2d 304, 307, 310 (7th Cir. 1987) (holding public comments by the Governor in conjunction with firing state employees is not a clearly established violation given the lack of precedent); Security \& Law Enforcement Employees v. Carey, 737 F.2d 187, 211 (2d Cir. 1984) (granting qualified immunity to correction officials who conducted random strip searches that were not clearly unconstitutional), overruled, Skinner v. Railway Labor Executives Ass'n, 109 S. Ct. 1402 (1989). As every lawyer knows, the best precedent is one that is on "all-fours" with the case at hand. Legal trivia buffs should know that a case with such a commanding precedent is known as a "goose" in Louisiana, a "spotted horse" in Alabama, a "cow" in Kansas, and a "white pony" in Texas. See Jefferson v. Ysleta Ind. School Dist., 817 F.2d 303, 305 n.1 (5th Cir. 1987). 
general agreement among the courts that constitutional claims requiring proof of intentional or malicious wrongdoing are not subject to an immunity defense. ${ }^{146}$

\section{Anderson v. Creighton: The Conduct Component}

The Court's focus in Harlow on whether the legal principle involved was clearly established, coupled with its insistence that the issue could be decided on summary judgment, without discovery, seemingly rendered irrelevant any claim that the lack of a clear factual precedent could be the basis for an immunity defense. This was true particularly when a relatively narrow legal principle governed the case. In a series of cases, the lower courts so ruled, precluding immunity in litigation involving well-established first and fourth amendment rights, notwithstanding the lack of specific factual precedent. ${ }^{147}$

Anderson v. Creighton ${ }^{148}$ swept away these decisions and created an additional basis for the qualified immunity defense: a governmental official is immune, despite the clear existence of a constitutional principle that governs the case, if a reasonable official would have believed that the conduct involved was legal. ${ }^{149}$ Anderson involved the warrantless search of the home of Robert and Sarisse Creighton for a fugitive (Sarisse Creighton's brother) sought in connection with a bank robbery that had been committed earlier in the day. When the agents came to the door, Robert Creighton requested to see a warrant but was told by the FBI agent, Anderson, that "[w]e don't have a search warrant [and] [we] don't need [one]; you watch too much T.V."150 The search of the house was fruitless and conducted with excessive force. ${ }^{151}$

146 See, e.g., Wade v. Hegner, 804 F.2d 67, 71-72 (7th Cir. 1986) (school official who warned of racial violence to discourage enrollment of black students); Lowe v. City of Monrovia, 775 F.2d 998, 1011 (9th Cir. 1985) (sex discrimination in hiring), amended, 784 F.2d 1407 (9th Cir. 1986); Hobson, 737 F.2d 29 (racially motivated infringement of first amendment rights); Stathos v. Bowden, 728 F.2d 15, 19-20 (1st Cir. 1984) (sex discrimination in salary).

147 See, e.g., Llaguno v. Mingey, 763 F.2d 1560, 1569 (7th Cir. 1985) (holding that subjective beliefs by arresting officers are no basis for immunity in light of established legal principles), cert. dismissed, 478 U.S. 1044 (1986); Creamer v. Porter, 754 F.2d 1311, 1317 (5th Cir. 1985) (same); Hobson, 737 F.2d at 27 (same).

148483 U.S. 635 (1987).

149 See id. at $639-40$.

I50 Creighton v. City of St. Paul, 766 F.2d 1269, 1270 (8th Cir. 1985), vacated sub nom. Anderson v. Creighton, 483 U.S. 635 (1987).

151 See id. at 1271 . 
The FBI claimed it had information that the fugitive had lived at the Creighton home and that his getaway car matched the Creightons' car. The FBI agent also asserted that the fugitive was likely to be armed and dangerous. These assertions were put in question by the plaintiffs who presented evidence directly contradicting significant aspects of the agent's factual defense. ${ }^{152}$

The plaintiffs successfully argued in the court of appeals that qualified immunity must fail as a matter of law. They asserted that the law governing searches of third party homes for fugitives was clearly established. Under then controlling Supreme Court precedent, such searches required a warrant unless the police had probable cause to believe the suspect was on the premises and exigent circumstances excused the failure to obtain a warrant. ${ }^{153}$ The government conceded the existence of settled legal principles, but claimed that qualified immunity still protected the agent unless he reasonably should have known at the time of the incident that his particular conduct violated the Constitution.

In an opinion by Justice Scalia, the Supreme Court held that qualified immunity protects public officials whose unconstitutional conduct is objectively reasonable. The Court recognized that the test of " objective legal reasonableness" "154 depends "upon the level of generality at which the relevant 'legal rule' is to be identified." 155 The Court cautioned against using too broad a rule, since that would eliminate qualified immunity. ${ }^{156}$ " $[\mathrm{T}]$ he right the official is alleged to have violated must have been 'clearly established' in a more particularized, and hence more relevant, sense: The contours of the right must be sufficiently clear that a reasonable official would understand that what he is doing violates that right." 157

The Court rejected the argument that its analysis should not apply in the fourth amendment context. ${ }^{158}$ The Creightons had argued that it would be anomalous to allow a qualified immunity defense where police failed to show probable cause and exigent circumstances, because such acts by definition were unreasonable under the fourth amendment. ${ }^{159}$ If the police failed to satisfy the

152 See id.

I53 See id. at 1273-77; Anderson, 483 U.S. at 638.

154 Anderson, 483 U.S. at 639 (quoting Harlow v. Fitzgerald, 457 U.S. 800, 815 (1982)).

$155 \mathrm{Id}$

156 See id. at 638-41.

157 Id. at 640.

158 See id. at 643.

159 See id. 
"practical, common-sense" requirement that the evidence show a "fair probability" of criminal wrongdoing, the plaintiffs argued, then they do not act reasonably. ${ }^{160}$ The Court stated that the language of the fourth amendment proscribing "unreasonable" searches and seizures did not preclude the possibility that an officer can act in an objectively reasonable fashion, even though in violation of the fourth amendment. $^{161}$ In the Court's view, determinations of probable cause are often quite difficult and officials should be held liable in damages only when their conduct was clearly proscribed. ${ }^{162}$

Harlow's standard was broader than necessary, immunizing actions which an official in some circumstances could reasonably be expected to know violate constitutional rights. By focusing on the applicable legal norms, however, it had the virtue of limiting immunity to situations where officials were most likely acting without specific constitutional guidance. ${ }^{163}$ What is particularly troubling about Anderson, therefore, is the adoption of a standard that looks to whether the conduct had been previously clearly proscribed in a setting where the constitutional standard itself is defined by notions of reasonableness. ${ }^{164}$ The requirement that probable cause exist for a

160 Id.

101 See id.

162 See id. at 643-45. It should be noted that the defense of mistake of law is generally highly unfavored. In the criminal law context, for example, the kind of mistake of law at issue in Anderson (whether certain facts constituted probable cause) is not permitted as a defense in most circumstances. See, e.g., Model Penal Code $\S 2.04(3)$ (b) (1962) (limiting mistake of law to situations where the actor relies on an official statement of the law "afterward determined to be invalid or erroneous"); $i d$. at $\$ 3.09(1)$ (a) (making unavailable a justification defense for law enforcement officers in the use of force or in arrest situations where the officer's "belief in the lawfulness of an arrest that he endeavors to effect by force is erroneous").

163 See infra text accompanying notes 278-81. For comments on Harlow and Anderson, see Gildin, supra note 82; Matasar, supra note 82, at 746 n.22; Comment, Rejecting Absolute Immunity for Federal Officials, 71 CALIF. L. REv. 1707 (1983) (discussing the holdings in Harlow and its progeny); Comment, Harlow v. Fitzgerald: The Lower Courts Implement the New Standard for Qualified Immunity Under Section 1983, 132 U. PA. L. REv. 901 (1984) (arguing that Harlow's pro-defense bias can result in the serious impairment of rights secured through $\$ 1983$ litigation); Note, An Examination of Immunity for Federal Executive Officials, 28 VILL. L. Rev. 956 (1983) (discussing the lack of uniformity in Supreme Court attempts to define a limited immunity standard); Note, Qualified Immunity for Government Officials: The Problem of Unconstitutional Purpose in Civil Rights Litigation, 95 YALE L.J. 126 (1985) [hereinafter Note, Unconstitutional Purpose] (arguing that after Harlow, the plaintiff's and defendant's claims raise "analytically distinct questions").

164 The Supreme Court has yet to address the question of what level of precedent is necessary to make a right "clearly established.". See Harlow v. Fitzgerald, 457 U.S. 800,818 n.32 (1982). The lower courts generally require a controlling precedent in the district or circuit in which the suit is brought. Absent 
search or arrest is a clearly settled principle of constitutional law. The question in these cases is not what technical legal rule applies; rather, it is whether a given set of facts meets the standard of a known rule. ${ }^{165} \mathrm{~A}$ finding of no probable cause for an arrest or a search is a finding that there was no reasonable basis for that particular police action. ${ }^{166}$ The probabilities which have to be assessed in making such a determination are not technical, "they are the factual and practical considerations of everyday life on which reasonable and prudent men, not legal technicians, act."167

Judge Jon O. Newman of the Court of Appeals for the Second Circuit made this point during his tenure as a district judge:

[T] he victim's cause of action for an arrest in violation of his Fourth Amendment rights requires an arrest without probable cause. To make out his case, the plaintiff must establish that a reasonably prudent police officer, under all the circumstances, would not have had probable cause to believe that he had committed a crime. Then, under Bivens, the officer still has a defense if he acted in good faith and has a reasonable belief in the validity of his action, that is, if he reasonably believed that he did have probable cause. But if the plaintiff's own case requires him to show an arrest that was not reasonably based on probable cause, what does the defense mean? Surely the officer could not reasonably believe that there was probable cause for an unlawful arrest, for an unlawful arrest is by definition an arrest for which a prudent police officer could not reasonably believe there was probable cause. ${ }^{168}$

The notion that one can reasonably and in good faith act in an

such authority, highly persuasive precedent in another circuit or the state supreme court may suffice. See, e.g., Wood v. Ostrander, 851 F.2d 1212, 1217-19 (9th Cir. 1988) (citing a Seventh Circuit case as controlling precedent); Robinson v. Bibb, 840 F.2d 349, 351 (6th Cir. 1988) ("In order to be clearly established, a question must be decided either by the highest state court in the state where the case arose, by a United States Court of Appeals, or by the Supreme Court."). But see Ohio Civil Serv. Employees Ass'n v. Seiter, 858 F.2d 1171, 1177-78 (6th Cir. 1988) ("A mere handful of decisions of other circuit and district courts, which are admittedly novel, cannot form the basis for a clearly established constitutional right in this circuit.")

165 See, e.g., Illinois v. Gates, 462 U.S. 213, 230-39 (1983) (applying a "totalityof-the-circumstances" approach to the known constitutional rule); Henry v. United States, 361 U.S. 98, 102 (1959) (holding that if an initial arrest is made without probable cause, the defendants may not be charged with the possession of contraband discovered after the arrest); Carroll v. United States, 267 U.S. 132, 16061 (1925) (applying a reasonableness of facts and circumstances test to establish probable cause).

166 See Henry, 361 U.S. at 104.

167 Gates, 462 U.S. at 231 (quoting Brinegar v. United States, 338 U.S. 160, 175 (1949)).

I6s Newman, supra note 43 , at 460 (footnote omitted). 
objectively unreasonable manner is more than a semantic contradiction. The cases defining probable cause give broad grounds to search or arrest. ${ }^{169}$ If an officer acts upon information which is insufficient to meet the probable cause standard, it is untenable to claim that the officer is entitled to immunity on a theory that the law had not clearly established that his particular conduct was illegal. If an officer did not have a sufficient basis to make a "practical, commonsense" decision that a "fair probability" of crime or evidence existed, he cannot have acted in an objectively reasonable manner.

In Llaguno v. Mingey, ${ }^{170}$ the Seventh Circuit analyzed the problem as follows:

The good sense of Harlow in withdrawing the issue of immunity from the jury is particularly evident in a case such as this, where the police are charged with having acted without probable cause. The question whether they had probable cause depends on what they reasonably believed with reference to the facts that confronted them, ... . To go on and instruct the jury further that even if the police acted without probable cause they should be exonerated if they reasonably (though erroneously) believed that they were acted reasonably is to confuse the jury and give the defendants two bites at the apple.

Justice Scalia's opinion for the Court in Anderson does little to rebut this argument. Justice Scalia concedes that the fourth amendment is defined by a reasonableness standard, but in his view, this is little more than an accident of language. It would have been possible for "an equally serviceable term, such as 'undue' searches and seizures," to have been used. ${ }^{171}$ Of course, even if the exact lan-

169 See, e.g., Gates, 462 U.S. at 230-46 (defining probable cause in terms of the "totality-of-the-circumstances," including the circumstances accompanying an anonymous letter that alleged drug trafficking). Further, the Supreme Court has allowed significant intrusions on the privacy interests of individuals on "reasonable suspicion" of wrongdoing. See, e.g., United States v. Sokolow, 109 S. Ct. 1581, 158587 (1989) (holding that Drug Enforcement Administration agents need not have "probable cause" before stopping a suspect, but only a "reasonable suspicion" supported by factual evidence); United States v. Sharpe, 470 U.S. 675, 682-83 (1985) (upholding a DEA agent's decision to stop an apparently overloaded truck in an area under surveillance for suspected drug trafficking); Adams v. Williams, 407 U.S. 143, $147-49$ (1972) (noting that an informant's tip was sufficient to allow the police to conduct a "stop and frisk"); Terry v. Ohio, 392 U.S. 1, 29-31 (1968) (validating a police decision to detain suspects after observing them "case" a store).

170763 F.2d 1560, 1569 (7th Cir. 1985), cert. dismissed, 478 U.S. 1044 (1986).

171 Anderson v. Creighton, 483 U.S. 635, 643 (1987). The Court's refusal to credit the explicit term of art in the fourth amendment is highly questionable. In Daniels v. Williams, 474 U.S. 327 (1986), the Court ruled that negligence was not sufficient to support a claim for a violation of the due process clause. The Court 
guage is disregarded, the Court still misses the point. The argument against application of qualified immunity is not based on the literal terminology of the fourth amendment; rather, it is supported by the standards the Court itself had adopted in defining the concept of probable cause. In this respect, the Court has repeatedly defined probable cause as "facts and circumstances. . [that] warrant a man of prudence and caution in believing that the offense has been committed," 172 and has stressed that the element of reasonableness inherent in the definition of probable cause "protects both the officer and the citizen." 173

The Court's assertion that "the precise content of most of the Constitution's civil-liberties guarantees rests upon an assessment of what accommodation between governmental need and individual freedom is reasonable," 174 may be an accurate description of constitutional decisionmaking, but it is seriously undermined by Anderson. By further accommodating governmental interests, the Court does more than immunize from liability a potentially broad range of unconstitutional conduct. In connection with decisions in other fourth amendment cases, Anderson may work to redefine substantive fourth amendment principles. The Court has already allowed for a "good faith" exception to the exclusionary rule in criminal cases where warrants are later declared invalid, ${ }^{175}$ and has adopted an identical standard of qualified immunity in civil suits based on unconstitutional warrants. ${ }^{176}$ Having extended this principle to warrantless searches in civil cases, if the Court applied it as well to limit the exclusionary rule in criminal cases involving searches without warrants, determination of fourth amendment probable cause and reasonableness issues would almost always turn on a subconstitutional standard: whether a reasonable police officer would have

placed significant emphasis on the exact language of the clause, stating that the term "deprive" in the fourteenth amendment "connotes more than a negligent act." Id. at 330. Apparently, semantics will be important in some contexts.

172 Carroll v. United States, 267 U.S. 132, 161 (1925) (quoting Stacey v. Emery, 97 U.S. 642, 645 (1878)); see also Brinegar v. United States, 338 U.S. I60, 175 (1949) (stating that probable cause involves "the factual and practical considerations of everyday life on which reasonable and prudent men, not legal technicians, act").

173 Henry v. United States, 361 U.S. 98, 102 (1959).

174 Anderson, 483 U.S. at 643-44.

175 See United States v. Leon, 468 U.S. 897, 924 (1984) (concluding that "the good-faith exception, turning as it does on objective reasonableness, should not be difficult to apply in practice").

176 See Malley v. Briggs, 475 U.S. 335, 341 (1986). 
believed that her improper actions comported with the fourth amendment. ${ }^{177}$

This approach would eventually leave no true corpus of law on the fourth amendment. Because rights are defined by court decisions, the substantive standards of the fourth amendment soon would be quite unknown, and the controlling standards would reflect the immunity rule, rather than the established concept of probable cause. ${ }^{178}$

The danger that an official's conduct will be governed by the subconstitutional immunity standard is not limited to cases in which the immunity doctrine is broadly applied. The same result can occur where the courts, in granting immunity, leave undecided the underlying constitutional issue. In addition, these cases leave officials without a clear guide for future conduct.

Borucki v. Ryan ${ }^{179}$ illustrates the danger. The case presented the question of whether a prosecutor unconstitutionally invades the privacy rights of a criminal defendant by disseminating confidential court-ordered psychiatric reports. At the time of the disclosure (1983), the Supreme Court had recognized a right of privacy with respect to certain confidential and personal matters, ${ }^{180}$ but had not defined its boundaries precisely, and had not addressed its implica-, tions for psychiatric records. The lower federal courts had generally found a right of privacy with respect to confidential medical and psychiatric records, but had recognized the balancing process that was necessary to determine whether release of the information was appropriate. ${ }^{181}$ Accordingly, the court in Borucki ruled that no clearly established right blocked dissemination of these records. One could disagree, ${ }^{182}$ but the most troubling problem Borucki

177 See Richardson v. Bonds, 860 F.2d 1427, 1434 (7th Cir. 1988) (holding that a sergeant acted in an objectively reasonable manner in arresting off-duty police officer); Osabutey v. Welch, 857 F.2d 220, 224 (4th Gir. 1988) (holding that information relied on by police was sufficient to give an objectively reasonable officer probable cause; there was no ruling on the merits of the fourth amendment claim). But see Sevigny v. Dicksey, 846 F.2d 953 (4th Cir. 1988) (finding that the false arrest was unreasonable under the circumstances and that there was no qualified immunity).

178 Even if the Court does not extend the "good faith" exception to the exclusionary rule for warrantless searches, the result is still unsatisfactory: only those charged with wrongdoing are provided a remedy.

179827 F.2d 836 (1st Cir. 1987).

180 See Whalen v. Roe, 429 U.S. 589, 599-600 (1977); Griswold v. Connecticut, 381 U.S. 479, 483 (1965).

181 See Borucki, 827 F.2d at 845-47.

182 See, e.g., United States v. Westinghouse Elec. Corp., 638 F.2d 570, 580 (3d 
presents is not the Court's determination of what was a clearly established right, but rather its use of qualified immunity to avoid a ruling on whether a right to privacy exists in this kind of situation.

The decision leaves prosecutors without guidance. The only clearly stated rule of Borucki is that in 1983 (and presumably in 1987), it was not clearly established that a criminal defendant had a privacy right to prevent disclosure of this kind of information. This is not to say, of course, that such a right does not exist; it very well may, but only in a conceptual vacuum. Thus, the only thing that is clearly established is that a defendant has no remedy if a prosecutor does disclose the information. Cynical prosecutors surely will understand this result; those with more integrity are left hanging over a constitutional abyss.

A similar approach was taken in Ramirez $v$. Webb, ${ }^{183}$ which involved a search for illegal aliens pursuant to a warrant that did not particularly describe the persons sought. The affidavit to the warrant described the suspected aliens as "hispanic-type males" and "undocumented aliens" who "spoke no English."184 The court canvassed the law as it existed at the time of the search and concluded that there was no clearly established principle that such a warrant must identify the suspects by name or description. Having reached that conclusion, the court was not obligated to decide whether the fourth amendment requires a higher degree of particularity. The court stated that the law "was not clear in 1980 and is not clear now." 185 The message delivered by this ruling, however, is clear: federal immigration authorities need not concern themselves with constitutional restrictions on their authority to search for illegal aliens, not because they do not exist, but because the courts need not rule on the question. Continued violation of rights in this class of cases will be excused as long as the immunity doctrine enables the Court to avoid the substantive issues.

In Walentas $v$. Lipper, ${ }^{186}$ a contractor claimed that his due process liberty and property rights were violated when, as a bidder for a city contract, he was defamed by a city official and lost business opportunities as a result. ${ }^{187}$ The plaintiff based his cause of action on due

Cir. 1980) (holding that the strong public interest in research and investigation outweighs the "minimal intrusion" into the privacy of employees' medical records).

183835 F.2d 1153 (6th Cir. 1987).

$184 \mathrm{Id}$. at 1155 .

185 Id. at 1157.

186862 F.2d 414 (2d Cir. 1988), cert. denied, 109 S. Ct. 1747 (1989).

$187 \mathrm{See}$ id. at 417. 
process principles that protect individuals from defamatory conduct and the consequential loss of employment or other governmental benefits. ${ }^{188}$ The court ruled that the question of whether a contractor who was seeking, as opposed to having already been granted, a government contract was protected by a due process liberty interest was not clearly established and dismissed the complaint on immunity grounds. ${ }^{189}$ The constitutional issue again was left unresolved, leaving government officials free to continue in potentially unconstitutional conduct. ${ }^{190}$ Given the extraordinary difficulties in securing injunctive relief in these situations, ${ }^{191}$ we may never know whether such a right exists. This is not prudence in avoiding unnecessary constitutional rulings. It is avoidance with a vengeance and with a substantial cost to our constitutional system.

The Court has given undue weight to society's interests in law enforcement and implementation of government policy. Harlow and Anderson provide government officials with far too broad a range of constitutional error, including situations where the unconstitutionality of their actions was foreshadowed by prior decisions or when they have acted with improper motive. Deterrence is diminished; constitutional law is left less developed; and the individual and societal interest in the vindication of rights is sacrificed.

It has been suggested that the failure to decide upon the constitutional issue will not result in a serious impediment to the development of constitutional doctrine. ${ }^{192}$ Suppression hearings in criminal cases, injunctive civil rights actions, and suits against municipalities

188 See id.; McKnight v. Southeastern Penn. Transp. Auth., 583 F.2d 1229, 123842 (3d Cir. 1978); cf. Paul v. Davis, 424 U.S. 693, 701-12 (1976); S \& D Maintenance Co. v. Goldin, 844 F.2d 962, 970-71 (2d Cir. 1988).

189 See Walentas, 862 F.2d at 421-22. In Doe v. United States Civil Serv. Comm'n, 483 F. Supp. 539 (S.D.N.Y. 1980), the court decided that such a right exists.

190 See Walenlas, 862 F.2d at 421; see also Edwards v. Gilbert, 867 F.2d 1271, 1275-76 (11th Cir. 1989) (holding that qualified immunity is established where an inmate had not previously attempted suicide and thereby avoiding a ruling on whether jail officials violated the Constitution by failing to prevent an inmate suicide); Barts v. Joyner, 865 F.2d 1187, 1189-95 (11th Cir. 1989) (declining to rule on whether warrantless arrest was based on sufficient probable cause because the law at the time was "ambiguous," so qualified immunity was established); Osabutey v. Welch, 857 F.2d 220 (4th Cir. 1988) (refusing to rule on whether affidavit established probable cause and holding that under Anderson the officer acted with objective reasonableness); Shabazz v. Coughlin, 852 F.2d 697, 700-02 (2d Cir. 1988) (holding that qualified immunity shielded prison officials from liability resulting from disciplining an inmate).

191 See City of Los Angeles v. Lyons, 461 U.S. 95, 112 (1983).

192 See Ohio Civil Serv. Employees Ass'n v. Seiter, 858 F.2d 1171, 1178 (6th Cir. 1988). 
(because they are not entitled to qualified immunity) are cited as alternative means of establishing constitutional doctrine. ${ }^{193}$ But as we have seen, ${ }^{194}$ the good faith exception to the exclusionary rule operates in a similar fashion in criminal cases that involve warrants, ${ }^{195}$ and suppression hearings will only be available where the person aggrieved by the police action is arrested. Furthermore, the Court has placed severe procedural restrictions on injunctive actions that have raised constitutional claims. Suits against municipalities require a substantial showing that a governmental "policy" caused the violation. ${ }^{196}$ Additionally, in a recent extension of judicial barriers to constitutional adjudication, the Court has placed significant limits on the power of a federal habeas corpus court to articulate new constitutional law. ${ }^{197}$

Finally, although a court certainly could decide both the constitutional and immunity issues, the nature of judicial decisionmaking makes this approach selective at best. When a court faces a difficult constitutional issue, it is tempting for it to finesse the constitutional question by holding that whether or not a violation has occurred, the right claimed was not clearly established. ${ }^{198}$

193 See id.

194 See supra note 175 and accompanying text.

195 See United States v. Leon, 468 U.S. 897, 908-13 (1984).

196 See City of Canton v. Harris, 109 S. Ct. 1197, 1203 (1989).

197 See, e.g., Teague v. Lane, 109 S. Ct. 1060, 1078 (1989) (holding that "habeas corpus cannot be used as a vehicle to create new constitutional rules of criminal procedure unless those rules would be applied retroactively to all defendants on collateral review" through exception). For a discussion of the government's arsenal of procedural defenses that avoid rulings on the merits of constitutional claims, see Fallon, supra note 67, at 13-30.

198 See, e.g., Osabutey v. Welch, 857 F.2d 220, 223-24 (4th Cir. 1988) (limiting the court's inquiry to whether defendant police officers could have reasonably believed their search was constitutional and avoiding a decision whether the search was actually constitutional); Walentas v. Lipper, 862 F.2d 414, 421-23 (2d Cir. 1988) (holding that the defendant is entitled to qualified immunity because the right alleged to be violated was not clearly established at time of the defendant's alleged malicious actions), cert. denied, 109 S. Ct. 1747 (1989). The Supreme Court has consistently mandated the avoidance of unnecessary constitutional adjudication. See, e.g., Webster v. Reproductive Health Servs., 109 S. Ct. 3040,3050 (1989) (noting that the Court is not empowered to decide "abstract propositions"); Ashwander v. Tennessee Valley Auth., 297 U.S. 288, 346 (1936) (Brandeis, J., concurring) (stating that the Court has developed a series of rules under which it has avoided passing on a large part of the constitutional questions pressed upon it). 


\section{Litigation Of The Immunity Defense After Anderson}

\section{A. The "Conduct" Component Applied to Other Constitutional Claims}

Anderson's extension of immunity to police misconduct in fourth amendment arrest and search cases does not indicate necessarily that the conduct element will be relevant in other constitutional contexts. A variety of factors, discussed below, will determine whether the Anderson doctrine controls.

\section{Intentional Misconduct}

Where the constitutional claim requires proof of intentional misconduct or a similarly high level of culpability, the notion of "objective reasonableness" may be irrelevant. Thus, an eighth or fourteenth amendment claim of "deliberate indifference" to an inmate's medical needs, ${ }^{199}$ or a fourteenth amendment claim of intentional race discrimination, ${ }^{200}$ should not be subject to an immunity defense. Once the plaintiff proves intentional or deliberately indifferent conduct, the official could not have acted reasonably. ${ }^{201}$

Underlying the Court's decision in Anderson was the notion that fourth amendment probable cause determinations often present hard legal questions, sometimes affected by subtle nuances of fact. Justice Scalia stated that the Court has had "difficulty . . . determining whether particular searches or seizures comport with the Fourth Amendment."202 While the reasonableness standard supplies the necessary protection for an officer in such a situation, it may be that an officer can make an "objectively reasonable" determination that probable cause exists even though a court may determine later that the search or seizure was unreasonable in terms of the fourth amend-

199 See Estelle v. Gamble, 429 U.S. 97, 104-06 (1976); Wood v. Sunn, 852 F.2d 1205, 1208 (9th Cir.), vacated, 880 F.2d 1011 (9th Cir. 1988).

200 See Wade v. Hegner, 804 F.2d 67, 72 (7th Cir. 1986); Hobson v. Wilson, 737 F.2d 1, 29-30 (D.C. Cir. 1984), cert. denied, 470 U.S. 1084 (1985).

201 This principle should extend to conspiracies to violate constitutional rights, see Easter House y. Felder, 852 F.2d 901 (7th Cir. 1988), rev'd, 879 F. 2d 1458 (7th Cir. 1989) (en banc), sex-based discrimination, see Lowe v. City of Monrovia, 775 F.2d 998 (9th Cir. 1985), and to infliction of cruel and unusual punishment, see Williams v. Bennett, 689 F.2d 1370 (11 th Cir. 1982), cert. denied, 464 U.S. 932 (1983); see also Jackson v. State of Mississippi, 644 F.2d 1142, 1146 (5th Cir. 1987) (holding that a prison inmate had a right to be free from cruel and unusual punishment in the form of inadequately screened prisoner guards).

202 Anderson v. Creighton, 483 U.S. 635, 644 (1987) (citing Malley v. Briggs, 475 U.S. 335,341 (1986)). 
ment. No such legal quandary exists for the defendant who deliberately violates one's rights.

\section{Excessive Force Claims}

Graham $v$. Connor ${ }^{203}$ decided which of two conceptually distinct tests would determine whether an officer's use of force was excessive and therefore a violation of the Constitution. Some Courts of Appeals had analyzed excessive force as a deprivation of liberty without due process of law, and required a showing of some significant level of severity of injury and conduct that either "shocks the conscience" or is otherwise malicious. ${ }^{204}$ Others had adopted a fourth amendment analysis. The relevant inquiry in those cases was whether an objectively reasonable officer would use the force at issue, regardless of the severity of the injuries or the defendant's subjective state of mind. ${ }^{205}$

In Graham, the Court ruled that excessive force claims arising out of arrests, investigatory stops, or other seizures of "free citizens" are properly analyzed under the fourth amendment's objective reasonableness standard. ${ }^{206}$ The Court stated that reasonableness is to be determined by the "facts and circumstances of each particular case, including the severity of the crime at issue, whether the suspect poses an immediate threat to the safety of the officers or others, and whether he is actively resisting arrest or attempting to evade arrest by flight." 207 Emphasizing the objective nature of the test, the Court stated that "[a]n officer's evil intentions will not make a Fourth Amendment violation out of an objectively reasonable use of force;

203109 S. Ct. 1865 (1989).

204 See, e.g., King v. Blankenship, 636 F.2d 70, 72-73 (4th Cir. 1980) (holding that unjustified infliction of bodily harm gives rise to $\S 1983$ liability); Johnson v. Glick, 481 F.2d 1028, 1033 (2d Cir.) (stating that the factors a court should consider include "the need for the application of force, the relationship between the need and the amount of force that was used, the extent of the injury inflicted, and whether force was applied . . . maliciously and sadistically for the very purpose of causing harm"), cert. denied, 414 U.S. 1033 (1973).

205 See, e.g., Lester v. City of Chicago, 830 F.2d 706, 712 (7th Cir. 1987) (noting that the fourth amendment test requires objective analysis without regard to the officer's underlying intent or the severity of the injury); New v. City of Minneapolis, 792 F.2d 724, 726 (8th Cir. 1986) (finding that "[i]f sufficiently egregious, a deliberate use of excessive force . . . can implicate the substantive due process right to be free from abusive governmental conduct").

206 See Graham, 109 S. Ct. at 1871.

207 Id. at 1872 (citing Tennessee v. Garner, 471 U.S. 1, 8-9 (1985)). 
nor will an officer's good intentions make an objectively unreasonable use of force constitutional."208

The Court did not decide whether qualified immunity is applicable in excessive force cases. ${ }^{209}$ A strong argument can be made that the use of more force than is necessary preempts an immunity defense. Given the situation a police officer faced, the question is whether the force used was justified and necessary; was it reasonable under the circumstances? This is not an area of the law that involves a "thicket" of legal opinions. While each case may present different facts, this well-established legal standard remains the same.

Probable cause rulings may present close legal questions because of the difficulty inherent in determining whether the facts justify an arrest or search. Case law may conflict and the weight a court ultimately might give to a certain factor (e.g. flight, furtive moves, informant statements) may not be fairly measurable by the officer on the street. Fourth amendment analysis looks to the totality of the factual circumstances to determine whether the officer's use of force was objectively reasonable. This is identical to the qualified immunity standard. A finding of unreasonable use of force establishes the constitutional claim and defeats immunity.

By contrast, the Court in Anderson ruled that the "reasonableness" standards of the fourth amendment and the doctrine of qualified immunity are analytically different concepts. Anderson determined that the police could reasonably, albeit mistakenly, decide that cause exists for a search or an arrest. But since objective reasonableness is the test for excessive force claims, it is conceptually incoherent to speak in terms of a qualified immunity defense. ${ }^{210}$

208 Id. (citations omitted).

209 See id. at 1873 n.12.

210 The Court noted that due process standards protect pre-trial detainees and that convicted prisoners would have to demonstrate cruel and unusual punishment for excessive force claims, at least in situations of prison disorders. See id. at 1871 n.10. Under the cruel and unusual standard the plaintiff must show malice. See Whitley v. Albers, 475 U.S. 312, 318-22 (1986). The Court left open the question "whether the Fourth Amendment continues to provide individuals with protection against the deliberate use of excessive physical force beyond the point at which arrest ends and pre-trial detention begins." Graham, 109 S. Ct. at 1871 n.10.

To the extent that the plaintiff must prove a due process or cruel and unusual punishment violation, the immunity defense surely would be inappropriate. Proof of severe injury, malice, or conduct that shocks the conscience is thoroughly inconsistent with the notion of objectively reasonable or good faith conduct. See Urbonya, Problematic Standards of Reasonableness: Qualified Immunity in Section 1983 Actions For a Police Officer's Use of Excessive Force, 62 TeMP. L.Q. 61, 97-98 (1989) (contending that "malicious conduct is per se objectively unreasonable for the purpose of qualified immunity"). 


\section{First Amendment Claims}

Certain first amendment principles are so well-established that courts have forcefully rejected defendants' assertions of qualified immunity despite claims that the conduct had not been previously proscribed. In Hobson $v$. Wilson, ${ }^{211}$ for example, the defendants had subjected political dissidents to the notorious FBI COINTELPRO (counter-intelligence program). The program consisted of a pattern of devious attempts to disrupt the plaintiffs' political activity. The court rejected the defendants' argument that because COINTELPRO had not previously been ruled unconstitutional, qualified immunity should preclude recovery. ${ }^{212}$

A number of important first amendment principles, however, require case-specific balancing of interests. For instance, when a public employee has been discharged for speech-related activity, the first amendment requires "a balance between the interests of the [employee], as a citizen, in commenting upon matters of public concern and the interest of the State, as an employer, in promoting the efficiency of the public services it provides ...."213 Thus, to accommodate governmental concerns, speech interests of employees are narrower than those of citizens in general.

Some courts have ruled that the balancing test, in combination with the fact-specific context of many of these cases, commands a broad application of qualified immunity. ${ }^{214}$ In Rakovich v. Wade, ${ }^{215}$ a member of the civil service commission sued police officials for damage to his reputation allegedly caused by a criminal investigation which he claimed was conducted in retaliation for his criticism of the police department. The court ruled that Mount Healthy City School District Board of Education v. Doyle ${ }^{216}$ required a plaintiff alleging retalia-

211737 F.2d 1 (D.C. Cir. 1984), cert. denied, 470 U.S. 1084 (1985).

212 See id. at 25-29.

213 Pickering v. Board of Educ., 391 U.S. 563, 568 (1968).

214 See, e.g., Rakovich v. Wade, 850 F.2d 1180, 1209-14 (7th Cir. 1988) (en banc) (implying that a "closely analogous case" is required in order to find a right clearly established), cert. denied, 109 S. Ct. 497 (1988); Egger v. Phillips, 710 F.2d 292, 315 (7th Cir. 1983) (en banc) (suggesting that it is not feasible to look to a general standard in order to determine whether an employee's freedom of speech has been abridged), cert. denied, 464 U.S. 918 (1983). But see Bennis v. Gable, 823 F.2d 723, 732-33 (3d Cir. 1987) (holding that the unsettled state of the law is not automatic grounds for qualified immunity, and that all that is required for a clearly established right is some factual correspondence so that officials can extrapolate the legal implications of their acts).

215850 F.2d 1180 (7th Cir.) (en banc), cert. denied, 109 S. Ct. 497 (1988).

216429 U.S. 274 (1977). 
tion for first amendment activity to prove that in the absence of an improper motive the action would not have been taken. ${ }^{217}$ The court applied a broad immunity standard, and finding no previous cases with similar factors, held that the plaintiff failed to prove a "total disregard of [his] first amendment rights."218

In Dartland v. Metropolitan Dade County, ${ }^{219}$ the Consumer Advocate of the County was fired for criticizing a plan to merge his office with another government department. He called the County Manager who proposed the plan a "paid lackey" with a "total misconception" of the Consumer Advocate's role. ${ }^{20}$ The Court of Appeals dismissed the complaint on immunity grounds (without reaching the merits of the claim), ruling that it was not clearly established that the comments were protected. ${ }^{221}$ The court stated that under Pickering and its progeny there is no "bright-line standard for determining when the State . . . may take action adverse to an . . employee's speech"; instead a case-by-case balancing test is necessary. ${ }^{222}$ In the court's view, "because of this case-by-case approach, '[t]here will rarely be a basis for [an] a priori judgment that the termination or discipline of a public employee violated "clearly established" constitutional rights.'

However a court might balance the appropriate factors in determining whether a first amendment violation occurred, the broad immunity defense adds another weight to the government's side of the scale. By permitting government officials to avoid liability on the theory that a reasonable official could have believed that an appropriate balance of factors in a specific case justified the dismissal, even though it did not, first amendment constitutional principles are subject to substantive redefinition in a large number of cases.

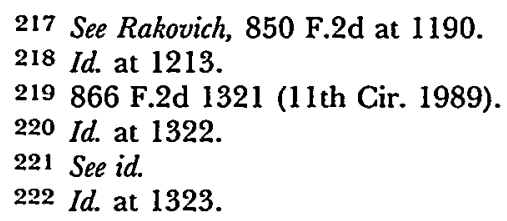

223 Id. (quoting Noyola v. Texas Dep't of Human Resources, 846 F.2d 1021, 1025 (5th Cir. 1988)); see also Walnut Properties, Inc. v. City of Whittier, 861 F.2d 1102 , 1112-13 (9th Cir. 1988) (holding that because."the defendants could not be expected to extrapolate a clear rule from the variety of circumstances faced by other courts," their actions could not be found to violate clearly established law), cert. denied, 109 S. Ct. 1641 (1989); of. Davis v. Scherer, 468 U.S. 183, 192 (1984) (indicating that the general due process standard is not sufficient to establish a right to a hearing). 


\section{B. Malice, Intent, and Subjective Beliefs}

In Harlow v. Fitzgerald, ${ }^{224}$ the Court ruled that "bare allegations of malice should not suffice to subject government officials either to the costs of trial or to the burdens of broad-reaching discovery."225 The Court therefore held that "government officials performing discretionary functions generally are shielded from liability for civil damages insofar as their conduct does not violate clearly established statutory rights of which a reasonable person would have known."226 The Court allowed that some officials may act maliciously, but concluded that the costs involved-extensive discovery against government officials, inability of courts to dismiss frivolous claims before trial, and increased exposure of government officials-outweighed the plaintiff's interests. ${ }^{227}$

In Anderson v. Creighton, ${ }^{228}$ the Court again sought to purge the qualified immunity doctrine of its subjective components: "The relevant question ... is the objective (albeit fact-specific) question whether a reasonable officer could have believed Anderson's warrantless search to be lawful, in light of clearly established law and the information the searching officers possessed. Anderson's subjective beliefs about the search are irrelevant." 229 The Court's failure to distinguish between general malice and the subjective intent that may be an integral aspect of the constitutional violation, however, has led to confusion over the scope of the Court's ruling. ${ }^{230}$

Whether conduct violates constitutional rights often depends upon the intent that characterizes the conduct:

[A] police officer does not violate a citizen's constitutional rights

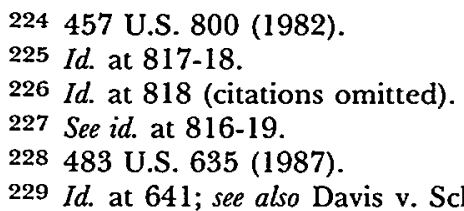
only objective reasonableness is relevant to the issue of qualified immunity).

230 See Pueblo Neighborhood Health Centers, Inc. v. Losavio, 847 F.2d 642, 648 (10th Cir. 1988); Halperin v. Kissinger, 807 F.2d 180, 184-88 (D.C. Cir. 1986); Hobson v. Wilson, 737 F.2d 1, 29 (D.C. Cir. 1984), cert. denied, 470 U.S. 1084 (1985). As a formal matter, Harlow addressed only the availability of the qualified immunity defense. It would be a mistake to read limitations on the elements of a claim for a constitutional tort into that limited holding. See Martin v. D. C. Metro. Police Dep't, 812 F.2d 1425, 1432 (D.C. Cir.), vacated in part, reh'g granted en banc, 817 F.2d 144 (D.C. Cir.), reh'g en banc dismissed, 824 F.2d 1240 (D.C. Cir. 1987); see also Note, Unconstitutional Purpose, supra note 163, at 137-47 (arguing that inquiry into an official's state of mind in order to establish a valid substantive claim should not be foreclosed if the Harlow standard is to permit redress for constitutional violations). 
for accidentally running into him on the street unless that police officer was trying to prevent the citizen from arriving at the polls to vote. If the officer was trying to hinder the person in voting, his mere verbal intimidation of the citizen might well state a constitutional claim. If the officer accidentally ran into a march of peaceful protestors, mangling and killing several, his careless driving alone would amount to no more than a State tort. If, however, he swerved to frighten the protestors, of whom he disapproved, his accidental bruising of even one makes out a First Amendment violation under $\S 1983$, being the natural result of an unconstitutional intent. Defamation of a citizen under color of a State law likewise would not state a constitutional claim unless that defamation was, say, intended as coercion of the citizen's exercise of a specific constitutional right. ${ }^{231}$

Constitutional intent may be relevant in two respects: where the plaintiff asserts that the defendant-official acted with a constitutionally prohibited state of mind, or where the plaintiff claims that the facially constitutional conduct was merely a pretext. ${ }^{232}$ State of mind is essential to proper adjudication of $\S 1983$ claims involving many constitutional claims. Fourteenth amendment claims of race ${ }^{233}$ or $\operatorname{sex}^{234}$ discrimination require proof that the defendant purposefully or intentionally has discriminated, and eighth amendment claims for lack of proper medical care require a showing of "deliberate indifference" to the prisoner's needs. ${ }^{235}$ Similarly, malicious prosecution claims require a showing that the proceedings were primarily undertaken for a purpose other than bringing the offender to justice. ${ }^{236}$

Where the plaintiff must establish the culpability element as part of the constitutional claim, denial of discovery on this issue would make it impossible to prove certain cases. The lower courts generally have recognized that claims of unconstitutional intent are not

231 Dandridge v. Police Dep't of Richmond, 566 F. Supp. 152, 160-61 (E.D. Va. 1983) (citation omitted).

232 See Comment, Pretext Searches and the Fourth Amendment: Unconstitutional Abuses of Power, 137 U. PA. L. REv. 1791 (1989); Note, Unconstitutional Purpose, supra note 163, at $135-36$.

233 See Gutierrez v. Municipal Ct., 838 F.2d 1031, 1049-51 (9th Cir. 1988).

234 See Poe v. Haydon, 853 F.2d 418, 430-32 (6th Cir. 1988), cert. denied, 109 S. Ct. 788 (1989).

235 See Estelle v. Gamble, 429 U.S. 97, 104 (1976); Wood v. Sunn, 852 F.2d 1205 (9th Cir. 1988); Boswell v. County of Sherburne, 849 F.2d 1117 (8th Cir. 1988), cert. denied, 109 S. Ct. 796 (1989).

236 See Rose v. Bartle, 871 F.2d 331, 349 (3d Cir. 1989); see also Wayte v. United States, 470 U.S. 598, 610 (1985) (requiring the petitioner in a selective prosecution claim to demonstrate that the government selected her because of her protest activities). 
automatically precluded by the immunity doctrine, ${ }^{237}$ but some courts have still refused to consider proof of such intent. ${ }^{238}$

Constitutional intent is also an issue where the plaintiff asserts that the justifications given for certain conduct were a pretext, and the actual intent was to deprive the plaintiff of constitutional rights. For example, in Tribble v. Gardner, ${ }^{239}$ an inmate claimed that routine body cavity searches were conducted not for any legitimate penological purpose, but as punishment, in violation of the fourth and eighth amendments. ${ }^{240}$ The court held that it was proper to inquire into the actual purpose of the searches since the element of motive was critical to a determination of whether the eighth amendment was violated. $^{241}$ In Halperin $v$. Kissinger, ${ }^{242}$ the court upheld the grant of immunity where the plaintiff had argued that the government's claim of a national security justification for a warrantless wiretap was pretextual. $^{243}$ The court agreed that the constitutionality of the wiretap turned on the underlying purpose, but gave great deference to the national security claim. 244

In the pretext cases, the motive of the official is relevant only to the degree that improper motive substantively affects the constitutional protection. In the fourth amendment area, for example, the Court often has rejected claims of unconstitutional conduct where objective facts support a search or arrest, but where the officer is

237 See Easter House v. Felder, 852 F.2d 901, 917-20 (7th Cir.), rev'd, 879 F.2d 1458 (7th Cir. 1989) (en banc); Abel v. Miller, 824 F.2d 1522, 1530-35 (7th Cir.), reh'g denied, 849 F.2d 1018 (7th Cir. 1988); Martin v. D.C. Metro. Police Dep't, 812 F.2d 1425, 1431 -33 (D.C. Cir.), vacated in part, reh'g, granted en banc 817 F.2d 144 (D.C. Cir.), reh'g en banc dismissed, 824 F.2d 1240 (D.C. Cir. 1987); Kenyatta v. Moore, 744 F.2d 1179, 1185-86 (5th Cir. 1984), cert. denied, 471 U.S. 1066 (1985); Hobson v. Wilson, 737 F.2d 1, 29-31 (D.C. Cir. 1984), cert. denied, 470 U.S. 1084 (1985).

238 See Halperin v. Kissinger, 807 F.2d 180, $184-88$ (D.C. Cir. 1986); Eggers v. Phillips, 710 F.2d 292, 314-15 (7th Cir.) (en banc), cert. denied, 464 U.S. 918 (1983). The decision in Eggers is particularly troubling. The court ruled that Harlow prevents inquiry into the reasons motivating a transfer of the plaintiff, an FBI agent, who claimed that the transfer was in retaliation for the exercise of his first amendment rights. On summary judgment, the court accepted the defendants' assertion that they transferred the plaintiff because of strained personal relations in the office, ignoring the plaintiff's assertion that this condition resulted from his protected activity in reporting a fellow agent for engaging in unlawful conduct. See id. at 296301.

239860 F.2d 321 (9th Cir. 1988), cert. denied, 109 S. Ct. 2087 (1989).

240 See id. at 326.

241 See id. at $326-27$.

242807 F.2d 180 (D.C. Cir. 1986).

243 See id. at 183.

244 See id. at $185,187-88$. 
alleged to have acted with an improper ulterior purpose. ${ }^{245}$ On the other hand, the Court has made it clear that purpose is often the critical factor in determining whether the governmental action infringes on free speech rights. ${ }^{246}$

Harlow and Anderson apparently foreclose proof of improper motive even where the defendant knew that the conduct was improper or was deliberately indifferent to the proper legal standards. ${ }^{247}$ The Court accorded great weight to the officials' interest in not being subjected to the costs of trial or extensive discovery on insubstantial claims. The Court recognized, but found to be less significant, the fact that in some instances the rule will protect the official who acts with the clearest intent to violate civil rights, or with disregard for controlling constitutional principles. To say that an objectively reasonable officer could have determined that the acts did not violate the Constitution, provides immunity not only to the officer who acts in good faith, but also to the officer who acts maliciously or without any concern for what the law actually requires. It is surely anomalous to provide immunity to such officials, particularly since the Court has imposed a burden on the plaintiff to demonstrate the official's disregard of established constitutional principles in order to proceed with her claim. ${ }^{248}$

245 See, e.g., Graham v. Connor, 109 S. Ct. 1865, 1872 (1989) (stating that "the question is whether the officers' actions are 'objectively reasonable' . . . without regard to their underlying intent or motivation"); Scott v. United States, 436 U.S. $128,137-38$ (1978) (rejecting the defendant's fourth amendment argument based on improper subjective intent).

246 See, e.g., Mount Healthy City School Dist. v. Doyle, 429 U.S. 274, 284-87 (1977) (finding that where a teacher demonstrated that protected speech was a motivating factor in his firing, school board had the burden of proving that it would have reached the same decision absent the protected conduct); Pickering v. Board of Educ., 391 U.S. 563, 574-75 (1968) (holding that the dismissal of a teacher for writing a letter critical of school board violated teacher's first amendment rights).

247 See Anderson v. Creighton, 483 U.S. 635, 641 (1987); Harlow v. Fitzgerald, 457 U.S. 800, 818-19 (1982). Compare Turner v. Dammon, 848 F.2d 440, 444-45 \& n.3 (4th Cir. 1988), where the court refused to engage in any inquiry into the subjective beliefs of the officers who had entered a bar at least one hundred times to conduct administrative searches for female "sitters" (women who solicit drink orders). The court refused to engage in such an inquiry because, it asserted, the "fourth amendment claims rise or fall on the objective reasonableness of the searches conducted." Id. The majority then noted that no objectively reasonable officer could have believed the conduct to be constitutional. Both the majority and the dissent concurred in the suggestion that the plaintiff would be entitled to summary judgment unless the defendant officers came forward with some basis for the high incidence of searches. See id. at 447.

248 In his concurring opinion in Harlow, Justice Brennan argued that a knowing or deliberate violation of the constitutional right should defeat the claim to qualified immunity: 
Anderson demonstrates the illogic of this approach. According to the Court, the facts with which Anderson was armed when he decided to conduct a warrantless entry and search of the plaintiff's home, although insufficient to meet the applicable fourth amendment test, possibly were sufficient to enable an officer reasonably to believe that probable cause and exigent circumstances were present. If Anderson, in fact, had considered the clearly established legal principles, but still came to an erroneous judgment as to his right to enter, one could at least say that the immunity was provided to an officer acting in good faith. But Anderson did no such thing. According to the plaintiff, when Anderson was asked whether he had a warrant, he replied, "I don't need a damn search warrant when I'm looking for a fugitive." 249 Anderson ignored clearly established principles governing his actions. Under these circumstances, it surely is facetious to claim that he acted reasonably or in good faith.

Permitting plaintiffs to litigate this issue need not lead to openended fishing expeditions. First, plaintiffs must allege facts that establish a constitutional violation. ${ }^{250}$ In some cases, the mere allegation of improper motive is not sufficient to transform otherwise constitutional conduct into unlawful acts, or to render "objectively reasonable" conduct unreasonable. ${ }^{251}$ Further, the courts have balanced the Harlow concern by imposing heightened pleading requirements. As the court in Hobson v. Wilson ${ }^{252}$ stated:

We recognize that in some instances, plaintiffs might allege facts demonstrating that defendants have acted lawfully, append a claim that they did so with an unconstitutional motive, and as a consequence usher defendants into discovery, and perhaps trial, with no hope of success on the merits. The result would be precisely the burden Harlow sought to prevent. Accordingly, in cases involving a claim that defendants acted with an unconstitutional motive, we will require that nonconclusory allegations of evidence of such intent must be present in a complaint for litigants to proceed to

This standard would not allow the official who actually knows that he was violating the law to escape liability for his actions, even if he could not "reasonably have been expected" to know what he actually did know. Thus the clever and unusually well-informed violator of constitutional rights will not evade just punishment for his crimes.

Harlow, 457 U.S. at 821 (Brennan, J., concurring) (citation omitted).

249 Creighton v. City of St. Paul, 766 F.2d 1269, 1271 (8th Cir. 1985), vacated sub nom. Anderson v. Creighton, 483 U.S. 635 (1987).

250 See Gomez v. Toledo, 446 U.S. 635, 640 (1980).

251 See Graham v. Connor, 109 S. Ct. 1865, 1872 (1989); Scott v. United States, 436 U.S. 128, 138 (1978).

252737 F.2d 1 (1984). 
discovery on the claim. The allegations on this issue need not be extensive, but they will have to be sufficiently precise to put defendants on notice of the nature of the claim and enable them to prepare a response and, where appropriate, a summary judgment motion on qualified immunity grounds. ${ }^{253}$

\section{Procedural Issues}

The type of qualified immunity granted in Harlow and Anderson also has had a substantial impact on the procedural aspects of litigation of the immunity defense. Indeed, as the Court has shaped and reshaped the substantive elements of the defense, it has had to adjust the procedural rules that control civil rights actions. The manner in which the Court has changed the doctrine raises serious doubts about the Court's stated rationales for this defense. In this section, I explore these procedural changes from a dual perspective: (1) the litigation of the qualified immunity defense and (2) the policy ends that the Court seems intent on achieving.

\section{Pleadings and Discovery.}

In the pre-Harlow stage of qualified immunity, the procedural rules concerning litigation of the pre-trial aspects of the defense were fairly well-settled. The burden of pleading and proving the affirmative defense was on the defendant. ${ }^{254}$ Since the issue of subjective intent was relevant, the defense was rarely susceptible to summary judgment disposition; trials were necessary to adjudicate this fact-specific issue. ${ }^{255}$

In Harlow, the Court redefined the substantive components of the qualified immunity doctrine with the explicit purpose of changing the procedural aspects of civil rights litigation. The Court expressed serious reservations about the "costs" of pre-trial discovery and trials to defendants, particularly high level government officials. The Court adopted a standard that could resolve the issue without discovery or trial. ${ }^{256}$ By framing the issue as to whether the law was clearly established, and removing any consideration of motive or bad faith, the Court assured litigants that the issue could be decided by either a motion to dismiss or a motion for summary

253 Id. at 29.

254 See Dennis v. Sparks, 449 U.S. 24, 29 (1980); Gomez, 446 U.S. at 640; Buller v. Buechler, 706 F.2d 844, 850 (8th Cir. 1983).

255 See supra notes $119 \& 125$ and accompanying text.

256 See Harlow v. Fitzgerald, 457 U.S. 800, 817-18 (1982). 
judgment. In the Court's view, this procedure would quickly terminate insubstantial suits against government officials. ${ }^{257}$

The Court reinforced the legal nature of the defense in Mitchell $v$. Forsyth, ${ }^{258}$ ruling that the denial of a qualified immunity claim could be appealed on an interlocutory basis. ${ }^{259}$ Recognizing that interlocutory appeals are limited to exclusively legal issues, the Court stated that the immunity decision presented "a question of law: whether the legal norms allegedly violated by the defendant were clearly established at the time of the challenged actions."260

Despite this unequivocal language, it was clear from the outset that the Court had swept with far too broad a brush. Even under Harlow, discovery was necessary in some cases. ${ }^{261}$ In addition, when Anderson modified Harlow to permit a defendant to claim that the factspecific issue of her conduct was material in the immunity calculus, any pretense that Harlow's definition of the defense was grounded on the need to allow for pre-trial resolution was severely undermined.

Anderson drives a wide wedge into the no-discovery doctrine. To the degree that a defendant asserts that previously established legal doctrine did not clearly proscribe her conduct, the threshold question is "what occurred?" In many civil rights cases there are sharp disputes over the facts. As the Harlow-Anderson rule does not purport to change the way in which factual issues are litigated, the court can properly dispense with discovery only when there is no dispute as to the underlying conduct or where the plaintiff's version would justify an immunity finding. Anderson itself was remanded, ${ }^{262}$ and the cases decided post-Anderson recognize the need to resolve certain factual issues in immunity cases. ${ }^{263}$

257 See id. at 818.

258472 U.S. 511 (1985).

259 See id. at 530.

260 Id. at 528.

261 See, e.g., Poe v. Haydon, 853 F.2d 418, 424 n.3, 425 (6th Cir. 1988) (rejecting contention that failing to seek resolution of qualified immunity issue before discovery constitutes a waiver of the defense), cert. denied, 109 S. Ct. 788 (1989); Kenyatta v. Moore, 744 F.2d 1179, 1185-86 (5th Cir. 1984) (stating that Harlow did not entirely eliminate subjective inquiry, and defendants lose part of the Harlow protection when they raise issues of fact regarding extraordinary circumstances which the plaintiff's evidence controverts).

262 See Anderson v. Creighton, 483 U.S. 635, 646 (1987).

263 See, e.g., Jones v. City \& County of Denver, 854 F.2d 1206, 1211 (10th Cir. 1988) (stating that where party opposing qualified immunity can show how discovery will enable her to rebut defendant's showing of objective reasonableness, summary judgement should not be granted); Geter v. Fortenberry, 849 F.2d 1550, 1554 (5th Cir. 1988) (noting that where the plaintiff's pleadings assert facts which, if proven, 
Furthermore, Anderson will preclude pre-trial adjudication of the immunity issue where the facts remain in dispute after discovery. In Anderson, there was a serious factual conflict over whether the agent had probable cause or even reasonable grounds to believe that the fugitive would be found at the home, and whether exigent circumstances justified a warrantless search. The Court ruled that discovery would be necessary if the facts as alleged by plaintiff did not provide the agent with an objectively reasonable basis for entering without a warrant. At that point, according to the Court, the motion for summary judgment "can be resolved."264 But what if the facts are still in dispute, thus precluding summary judgment under the usual Rule 56 standards? ${ }^{265}$

Plainly, the factual issues must be resolved at trial. I address below the interesting problems posed in the trial resolution of qualified immunity, ${ }^{266}$ but the Court's full circle should not be overlooked. In Harlow, the Court took the novel step of modifying substantive doctrine-the standards for qualified immunity defense-to satisfy concerns about procedural problems posed by civil rights litigation. The burden on government officials of discovery and trial was, according to the Court, simply unjustified in certain circumstances. Then, in Anderson, faced with a claim by officials that a wider range of immunity should be provided, the Court granted the immunity claim, thus undermining the rationale of Harlow and Forsyth by readjusting the procedural rules to permit the very discovery thought to be so onerous in Harlow. The assurances of a purely legal approach to the immunity issue given in Harlow were subordinated to the perceived needs for even broader immunity for public officials.

would defeat a qualified immunity defense, limited discovery tailored to the qualified immunity issue should be permitted).

264 Anderson, 483 U.S at 646 n.6.

265 Summary judgment is appropriate where "there is no genuine issue as to any material fact and ... the moving party is entitled to a judgment as a matter of law." Fed. R. Civ. P. 56 (c). In Celotex Corp. v. Catrett, 477 U.S. 317 (1986), and Anderson v. Liberty Lobby, Inc., 477 U.S. 242 (1986), the Court refined the procedural aspects of summary judgment, ruling that the non-moving party must show "specific facts" presenting a genuine issue for trial, and allowing for discovery to develop these facts. See Celotex, 477 U.S. at 323-24, 326; Liberty Lobby, 477 U.S. at 248,250 . This standard should be applicable in the immunity context. See, e.g., Rich v. Dollar, 841 F.2d 1558, 1565 (11th Cir. 1988) (noting that denial or grant of summary judgment based on qualified immunity turns on whether pleadings reveal a genuine issue of material fact as to whether the defendant's conduct violated a right accruing to the plaintiff under existing law).

266 See infra text accompanying notes 278-82. 


\section{Interlocutory Appeals.}

In Mitchell v. Forsyth, ${ }^{267}$ the Court ruled that the denial of a defendant's pre-trial claim to qualified immunity could be appealed on an interlocutory basis. ${ }^{268}$ The Court reasoned that immunity was itself a defense to suit and that the benefits of immunity to prevent the trial of insubstantial claims that Harlow sought to foster would be lost if immediate appeals were not allowed. ${ }^{269}$ Furthermore, the Court emphasized the strictly legal nature of the immunity issue, which in theory would permit an appellate court to decide the question of whether the law relied upon by the plaintiff was clearly established. ${ }^{270}$

The Forsyth dissent properly pointed out the flaws in the Court's analysis, ${ }^{271}$ but even accepting the Court's legal premises, it is fairly obvious that substantial difficulties are inherent in this type of pretrial appeal. First, as discussed above, ${ }^{272}$ even under Harlow, questions of fact would preclude appellate resolution of the immunity issue. Anderson expressly acknowledged the factual-conflict problem, but gave no guidance on how it should affect the appellate process. ${ }^{273}$ Presumably, if the case is not appropriate for resolution on summary judgment, it cannot be resolved on appeal. Defendant appeals, however, are permitted at the instance of the defendant, and the delays and costs involved are usually a far more significant burden for the plaintiff. ${ }^{274}$

Second, the proper scope of the interlocutory appeal raises

267472 U.S. 511 (1985).

268 See id. at 530.

269 See id. at 526.

270 See id. at 528 \& n.9.

271 See id. at 545-56 (Brennan, J., dissenting).

272 See supra text accompanying note 261.

273 See Anderson v. Creighton, 483 U.S. 635, 646 n.6 (1987).

274 The Court has not placed any limits on the number of interlocutory appeals that might be available to the defendant. Several circuit courts, however, noting the possible abuse of the appellate process, have restricted interlocutory appeals. See, e.g., Apostol v. Gallion, 870 F.2d 1335, 1338-39 (7th Cir. 1989) (noting that defendants who "play games" with a district court's schedule forfeit their entitlement to a pre-trial appeal); Unwin v. Campbell, 863 F.2d 124, 132 n.5 (Ist Cir. 1988) (allowing only one interlocutory appeal); Prisco v. United States Dep't of Justice, 851 F.2d 93, 96 (3d Cir. 1988) (noting that there may be no appeal from a denial of summary judgment on immunity grounds where injunctive relief is also requested); Walsh v. Mellas, 837 F.2d 789, 800 (7th Cir.) (stating that the defendant loses the right to advance the qualified immunity defense on appeal if she failed to raise it at trial), cert. denied, 108 S. Ct. 2832 (1988); Kennedy v. City of Cleveland, 797 F.2d 297, 301 (6th Cir. 1986) (noting that appealable orders must be appealed within the time limit set by law or the right to appeal is considered waived). 
questions. When the defendant claims on appeal not only that the law was not clearly established (or that the conduct was not clearly proscribed), but also that the evidence fails to implicate the defendant or is insufficient as a matter of law, should the appellate court decide these issues? Very broadly speaking, the failure to connect a particular defendant to the illegal conduct or proof of certain affirmative defense means that the plaintiff has failed to state a claim of clearly established law against this defendant. Interlocutory appellate review of these issues under the guise of immunity will entangle the appellate courts in unjustified and unnecessary appeals. For example, in Unwin v. Campbell, ${ }^{275}$ the court agreed to decide whether an issue of fact surrounding the qualified immunity claim was sufficient to allow the case to proceed to trial. ${ }^{276}$ In dissent, Judge Breyer cogently noted the dangers of such an approach:

Factual issues in $\S 1983$ cases . . . often concern such nebulous matters as whether the defendant acted with "discriminatory intent," matters in respect to which a record may contain vast amounts of conflicting affidavits, depositions, and other discovery material. ... [D]istrict courts in such cases may deny summary judgment simply because the record is so complex that, from the perspective of efficient judicial caseload management, it is best to send the case to the jury.... If the jury decides for the defendant, the case is over. If the jury decides for the plaintiff, the issue becomes one of sufficiency of the evidence at trial, not sufficiency of the oftenless-comprehensible documentary evidence presented at the summary judgment stage. The summary judgment question has "washed out"....

It would be anomalous to let a defendant force both a district court and an appeals court to pore over a complex record to decide whether the evidence is sufficient to go to a jury, when the practical solution in hard cases is simply to hold the jury trial. ${ }^{277}$

The appellate courts must draw some specific limits on the scope of immunity appeals to avoid interlocutory review of Rule

275863 F.2d 124 (1st Cir. 1988).

276 See id. at 132. The court determined that while two defendants were entitled to qualified immunity, the facts regarding four other defendants were in dispute, so the qualified immunity issue could not be resolved in summary judgment for the latter defendants. See id. at 133, 136.

277 Id. at 139-40 (Breyer, J., dissenting); see also Ryan v. Burlington County, 860 F.2d 1199, 1203 nn.7-8 (3d Cir. 1988) (leaving open the question whether the "I didn't do it" defense is cognizable on a qualified immunity appeal), cert. denied, $109 \mathrm{~S}$. Ct. 1745 (1989). 
12(b)(6) issues as well as intrusion on reliable trial court litigation practices.

\section{Trial of the Immunity Defense}

The Supreme Court has placed substantial emphasis on pre-trial adjudication of the qualified immunity issue. In Anderson, the Court concluded that discovery would be necessary in some cases, ${ }^{278}$ but the Court did not address the question of how the issue is to be resolved if the existence of material issues of fact preclude summary judgment. Few cases still should have a qualified immunity issue at the point of jury determination of liability. Cases involving the Harlow legal question of the state of the law at the time of the incident will have resolved this issue before trial. ${ }^{279}$

Even in those cases where "conduct" is at issue and the parties present conflicting facts, if the jury accepts the plaintiff's side, qualified immunity will be inapplicable as this version of the incident would have been considered on any pretrial motions. If the jury accepts the defendant's version, that too in most cases will be dispositive on the merits of the constitutional claim. Only a case in which the facts as the jury found them constitute conduct that a reasonably objective official would not have known was unconstitutional would present a "jury question." Assuming that the issue is so presented, resolution is possible by submission of the matter with appropriate instructions to the jury or upon special interrogatories to the jury on the factual conflicts. In the latter procedure, once the jury decides the facts and finds the underlying constitutional deprivation, the court then determines the immunity question as a matter of law.

Most courts continue to recognize that qualified immunity is a legal issue that should not be submitted to the jury. ${ }^{280}$ How would

278 See Anderson v. Creighton, 483 U.S. 635, 646 n.6 (1987) (stating that on remand the court should first determine whether a reasonable officer could have thought that defendant's alleged actions were legal).

279 See id.

280 See, e.g., Alvarado v. Picur, 859 F.2d 448, 451 (7th Cir. 1988) (stating that the question of qualified immunity is one for the court, not the jury); Rakovich v. Wade, 850 F.2d 1180, 1201-02 (7th Cir.) (stating that the jury's role does not extend to determination of qualified immunity because that is a question of law for the court), cert. denied, 109 S. Ct. 497 (1988); Holt v. Artis, 843 F.2d 242, 245-46 (6th Cir. 1988) (noting that the court should have determined well before the trial that the good faith defense was not available to the defendants as a matter of law); Garionis v. Newton, 827 F.2d 306, 309 (8th Cir. 1987) (holding that district court erred in submitting qualified immunity issue to the jury because it is a question of law); Warren v. City of Lincoln, 816 F.2d 1254, 1261 (8th Cir. 1987) (stating that the question of whether defendants are entitled to qualified immunity is a question of law to be determined 
the court explain narrow distinctions or subtle constitutional doctrine? Is the judge to give the jury all the judicial opinions that touched on this issue? In Alvarado v. Picur, ${ }^{281}$ the court noted the intrinsic difficulties in submitting this issue to the jury:

How was the jury supposed to determine the law on the dates in question? And, if the jury somehow could determine the law on the dates in question, how was it supposed to determine if that law was "clearly established?" As plaintiff's counsel asked, "How is the jury ever going to know that?" The trial court had "no problem" with the above instruction. We do. The question of qualified immunity is a question of law for the court, not for the jury. ${ }^{282}$

If a fact finder must resolve the issue, the courts should continue to view the ultimate question as one of law and should decide the issue upon specific findings of fact.

\section{A Principled Immunity Doctrine}

Formulating the proper standard for qualified immunity presents several fundamental questions concerning the appropriate balance among several competing interests: (1) compensation for persons whose rights are violated; (2) deterrence of unconstitutional actions by government officials; (3) vindication of constitutional rights; (4) protection of government officials from frivolous suits and from liability when they have acted in good faith and in accordance with established standards; and (5) vigorous and effective enforcement of legal and government policies.

by the trial court), rev'd on reh'g en banc, 864 F.2d 1436 (8th Cir.), cert. denied, 109 S. Ct. 2431 (1989). But see Melear v. Spears, 862 F.2d 1177, 1184 n.7 (5th Cir. 1989) (stating that jury could properly determine reasonableness of defendant's actions after being instructed according to the Anderson/Harlow standard); Thorsted v. Kelly, 858 F.2d 571, 575-76 (9th Cir. 1988) (stating that qualified immunity from damages may be asserted at trial and jury may evaluate objective reasonableness). In Melear, Judge Higginbotham suggested the use of special interrogatories in a concurring opinion, See Melear, 862 F.2d at 1188 (Higginbotham, J., concurring).

281859 F.2d 448 (7th Cir. 1988).

282 Id. at 451. In Easter House v. Felder, 852 F.2d 901, 916 n.16 (7th Cir. 1988), rev'd on reh'g en banc, 879 F.2d 1458 (7th Cir. 1989), the court noted a potential argument for allowing evidence of subjective factors (malice, bias) at trial, if factual disputes have precluded summary judgment: in such cases a full trial is necessary and any added burden on the defendants is outweighed "by the value of deterring officials and compensating plaintiffs in cases where defendants knew their actions were unlawful." Id.; see also McElveen v. County of Prince William, 725 F.2d 954, 957-58 (4th Cir.) ("Although the Harlow Court indicated that the good-faith defense turns primarily on objective factors, it did not hold that an exclusively objective standard was to be applied to claims that proceeded to trial." (citation omitted)), cert. denied, 469 U.S. 819 (1984). 
Initially, a serious question exists whether the Court should use the qualified immunity doctrine to impose a judicially crafted balance of these factors. Normally the legislature should decide the policy questions inherent in this process, particularly if it has the means of protecting the very interests that an immunity defense would serve. Congress may make the necessary adjustments in the statutory framework. ${ }^{283}$ Even in the absence of congressional action, a municipality that seeks to encourage the vigorous enforcement of laws or wants to protect officers from "unfair" damage awards can indemnify those officials in appropriate cases. Indemnification would protect valid government interests and at the same time would provide for the vindication of constitutional rights through compensation of the victim of the constitutional tort. ${ }^{284}$

The Court, of course, has concluded that qualified immunity is necessary to further interests in effective government. Even granting that role, judicial construction of an immunity defense in constitutional tort litigation should not replicate the balancing already undertaken with respect to the definition of substantive constitutional rights or the scope of $\S 1983$. Nor should it provide the means for an end-run around settled judicial interpretation of these provisions. The Court has stressed repeatedly the deterrent and compensatory purposes of $\S 1983,{ }^{285}$ and it should tread lightly in recognizing defenses that interfere with these legislative goals.

Properly balancing these interests in a constitutional tort system presents substantial difficulty. ${ }^{286}$ Calibrating the system to achieve

283 See Tower v. Glover, 467 U.S. 914, 922-23 (1984).

284 Local governments often obtain insurance coverage for constitutional torts. Others are self-insured and pay judgments or settlements in cases involving public employees. See P. Schuck, supra note 43, at 85-88. In Anderson, however, the Court ruled that Justice Department regulations providing for discretionary indemnification of FBI agents in Bivens actions did not justify denial of qualified immunity. See Anderson v. Creighton, 483 U.S. 635, 641 n.3 (1987).

$285 \mathrm{See}$ Smith v. Wade, 461 U.S. 30, 54-56 (1983) (holding that punitive damages in a $\S 1983$ action are appropriate in certain cases and concluding that "society has an interest in deterring and punishing all intentional or reckless invasions of the rights of others"); Owen v. City of Independence, 445 U.S. 622, 651 (1980) (stating that "[a] damages remedy against the offending party is a vital component of any scheme for vindicating cherished constitutional guarantees"); Carey v. Piphus, 435 U.S. 247, 254 (1978) ("The basic purpose of a $\$ 1983$ damages award should be to compensate persons for injuries caused by the deprivation of constitutional rights.").

286 Commentators have produced extensive literature on the policy issues involved in weighing the appropriate factors. See P. Sснuск, supra note 43, at 59-81; Bermann, supra note 43, at 1175-203; Cass, Damage Suits Against Public Officers, 129 U. PA. L. Rev. $1110,1119-74$ (1981); Foote, supra note 43, at 496-508; Meltzer, supra note 43, at 267-328; Newman, supra note 43, at 447-58; Posner, Excessive Sanctions for 
the optimal level of deterrence, to provide fair and adequate compensation, and to allow for vigorous implementation and enforcement of government policies requires a careful assessment of issues of individual and enterprise liability, the scope of remedies in civil litigation, and the impact of other remedies, including the criminal law exclusionary rule, internal governmental disciplinary proceedings, and criminal prosecution of government officials. These judgments are further complicated by the vastly different types of conduct addressed in constitutional tort litigation, ranging from the isolated, unauthorized act of a low-level police officer to the broadest policymaking decisions of high government officials. As the conduct that will be addressed lacks uniformity, and the potential official defendants are so differently situated, a unitary immunity doctrine is unlikely to have a fair or effective impact on these very disparate areas.

Moreover, the immunity doctrine does not operate in isolation. Significant interplay occurs, for example, between the doctrines of qualified immunity and municipal liability with respect to issues of compensation and deterrence. ${ }^{287}$ If a municipality compensates victims of civil rights violations pursuant either to statutorily imposed liability or indirectly by indemnification, the plaintiff's rights are vindicated while qualified immunity protects the individual officer. The appropriate limits of the immunity doctrine must therefore be analyzed in the overall context of civil rights actions.

Viewing the constitutional confrontation ex ante, the question is how best to motivate the official to act within constitutional constraints without significant derogation of the interest in vigorous enforcement of governmental policies. Where the constitutional standard is not reasonably foreseeable, the concern that the official will be risk-adverse is most compelling. In these situations, holding the official personally liable may be unfair. ${ }^{288}$ But surely overdeter-

Governmental Misconduct in Criminal Cases, 57 WASH. L. REv. 635, 638-41 (1982); see also G. Calabresi, The Costs of Accidents 24-33, 68-69 (1970) (balancing the costs of accidents with the costs of deterrence and compensation).

287 See, e.g., Owen, 445 U.S. at 656 (holding that "the inhibiting effect [on an official's decisiveness and judgment] is significantly reduced . . . when the threat of personal liability is removed"); P. ScHucK, supra note 43 , at $82-88$ (concluding that shifting the liability to the government still may jeopardize vigorous official decisionmaking).

288 See Pierson v. Ray, 386 U.S. 547, 555 (1967), modified, Harlow v. Fitzgerald, 457 U.S. 800 (1982). Immunity opinions often assume that if liability always flows from constitutional violations, officials will not only be risk-adverse, but competent people may choose not to serve in government. See, e.g., Harlow v. Fitzgerald, 457 U.S. $800,813-14$ (1982) (stating that the threat of liability for constitutional 
rence is not a legitimate concern if liability is imposed in situations like that addressed in Anderson, where the legal principle is well established, but where the conduct at issue has not been previously adjudicated. As discussed above, in fourth amendment cases the standard is quite undemanding; whatever percentage of assuredness that is required leaves wide room for reasonable error. Furthermore, to the degree that an officer acts in good faith in close situations, the governmental entity can hold her harmless.

Viewing the constitutional violation ex post, different considerations come into play. The question becomes: "Who, if anyone, pays?" Should the official pay damages in all situations where a right is violated? If not, should enterprise liability be imposed to ensure compensation? If enterprise liability is imposed, what course should the government take with respect to indemnification and possible discipline of the errant official? ${ }^{289}$

violations may cause public officials to divert "official energy from pressing public issues ... [ [and deter] able citizens from acceptance of public office"); Spalding v. Vilas, 161 U.S. 483,498 (1896) (stating that the head of an executive branch department "should not be under an apprehension that the motives that control his official conduct may, at any time, become the subject of inquiry in a civil suit for damages" as this "would seriously cripple the proper and effective administration of public affairs"); Cass, supra note 286, at 1153-64 (assessing the possible overdeterrence effects of liability and responses that might limit those effects). In Gregoire v. Biddle, 177 F.2d 579, 581 (2d Cir. 1949), cert. denied, 339 U.S. 949 (1950), Judge Learned Hand ruled that absolute immunity from common law tort actions was necessary:

It does indeed go without saying that an official, who is in fact guilty of using his powers to vent his spleen upon others, or for any other personal motive not connected with the public good, should not escape liability for the injuries he may so cause; and, if it were possible in practice to confine such complaints to the guilty, it would be monstrous to deny recovery. The justification for doing so is that it is impossible to know whether the claim is well founded until the case has been tried, and that to submit all officials, the innocent as well as the guilty, to the burden of a trial and to the inevitable danger of its outcome, would dampen the ardor of all but the most resolute, or the most irresponsible, in the unflinching discharge of their duties.... In this instance it has been thought in the end better to leave unredressed the wrongs done by dishonest officers than to subject those who try to do their duty to the constant dread of retaliation.

No empirical evidence has been presented, however, supporting the notion that officials would not serve or would be so seriously risk-adverse as to impair governmental functions. In fact, because government generally pays judgments against its officers (and in most cases provides free legal representation), the fear of overdeterrence is not valid. See Cass, supra note 286, at 1153-74; Eisenberg \& Schwab, The Reality of Constitutional Tort Litigation, 72 Connel. L. Rev. 641, 693-95 (1987); Project, Suing the Police in Federal Court, 88 Yale L.J. 781, 809-18 (1979).

289 Municipal liability under $\S 1983$ is possible under the Monell doctrine. See supra notes $39-48$ and accompanying text. In Owen v. City of Independence, 445 
The Court's current approach unnecessarily subordinates constitutional protections to interests of governmental efficiency. Requiring a plaintiff to demonstrate that the law was clearly established and that the conduct causing complaint was plainly proscribed by these legal principles immunizes serious governmental misconduct. Immunity is justified only in situations when the law changes or when prior development did not foreshadow the constitutional principle. Furthermore, a qualified immunity standard that allows for a defense of "reasonable" violations of rights invites a re-balancing of the substantive constitutional equation and the double counting of the governmental interests. ${ }^{290}$

Proponents of a broad immunity argue that this standard is necessary to protect against overdeterrence. According to this theory, if officials are accountable in damages when the proper course of conduct is not clearly predictable, the officials will steer too far from the line, resulting in a loss of governmental effectiveness. ${ }^{291}$ This argument would have more force if the governmental interests had not already been taken into account. Consider a police officer's right to use deadly force. In Tennessee v. Garner, ${ }^{292}$ the Court ruled that an officer may use deadly force to apprehend a criminal suspect when that person poses a significant threat of physical harm to the officer or others. The fourth amendment standard provides a significant margin of error for the officer; no liability accrues if the officer reasonably believed that the suspect threatened the use of a deadly

U.S. $622,638,657$ (1980), the Court ruled that municipalities do not enjoy qualified immunity from suits for damages under $\$ 1983$. Where a federal employee is the alleged tort-feasor, a suit may lie against the United States under the Federal Torts Claims Act, 28 U.S.C. $\$ \S 2671-80$ (1982 \& Supp. V 1987). In such cases, qualified immunity probably will not be a defense. See, e.g., Arnsberg v. United States, 549 F. Supp. 55, 57 (D. Or. 1982) (observing that the victim of a constitutional violation at the hands of a federal official can sue either the individual official under Bivens or the United States under the Federal Torts Claims Act and that "good faith defense[s] available to individual government officers [are] not available to the government itself'), modified, 757 F.2d 971 (9th Cir. 1985), cert. denied, 475 U.S. 1010 (1986); Townsend v. Carmel, 494 F. Supp. 30, 36 (D.D.C. 1980) (concluding that "[i]t is clear that the federal government is vicariously liable for the torts of assault, battery, false arrest, and false imprisonment if those torts were committed by federal law enforcement officers"). But see Norton v. United States, 581 F.2d 390, 394-97 (4th Cir.) (allowing, in a pre-Owen ruling, vicarious liability against the government only where individual liability under Bivens also lies), cert. denied, 439 U.S. 1003 (1978).

290 See supra note 174 and accompanying text.

291 See supra note 43.

292471 U.S. 1 (1985). 
weapon or "committed a crime involving the infliction or threatened infliction of serious physical harm."293

The Constitution's prohibition on the use of deadly force where the requisite reasonable belief does not exist is not a strict liability concept. Errors of judgment, if reasonable, are protected. Deadly force may be justified without an actual threat of violence. No further insulation from liability is needed to ensure society's interest in the vindication of its criminal laws. If an officer cannot show an "articulable basis to think [the suspect] was armed," officer accountable in damages does not deter legitimate law enforcement. By contrast, extending immunity to the unreasonable use of deadly force disallows compensation, prevents the vindication of rights, and erodes fourth amendment protections.

In part, the position one takes on this issue reflects the weight one gives in our constitutional system to the perspective of the victim or the perpetrator. Valuing the preservation and vindication of constitutional rights places the burden more on the officials to demonstrate compelling reasons for the violation of the rights. Seen through the eyes of government officials attempting to carry out policy in largely uncharted waters, imposing liability is unfair when the official is not clearly on notice that her questioned actions are unconstitutional. The Court increasingly perceives the issue from the side of the official-perpetrator. By requiring proof of clearly established law, the Court seeks to limit liability to cases in which the official acts with a substantial degree of culpability. Indeed, by requiring precedent clear enough to eliminate reasonable disagreement about the constitutionality of the officer's actions, the Court imposes a culpability element that comes uncomfortably close to the "specific intent" requirement that the Court expressly rejected in Monroe $v$. Pape. ${ }^{295}$ The Court has imposed similar state of mind limitations in other areas where individuals seek remedies for police or prosecutorial misconduct. For example, due process claims are precluded as a matter of constitutional law where an official acts only negligently. ${ }^{296}$ In criminal law, the Court has repeatedly refused to

293 Id. at 11.

$294 I d$. at 20.

295365 U.S. 167 (1961), overruled in part, Monell v. New York Dep't of Social Servs., 436 U.S. 658 (1978); cf. Williamson v. Handy Button Mach. Co., 817 F.2d 1290,1294 (7th Cir. 1987) (affirming liability in $\$ 1981$ action for actual damage to victim, whether or not the defendant intended such a violation).

296 See Davidson v. Cannon, 474 U.S. 344, 347 (1986); Daniels v. Williams, 474 U.S. 327,333 (1986). 
impose sanctions for violations of a defendant's rights absent bad faith or intentional misconduct. ${ }^{297}$ Plainly, this Court views the level of culpability of the errant government official as a major factor in the calculus of appropriate remedies.

The equilibrium reached by the Harlow-Anderson test is not sound. The governmental interest is sufficiently protected by a standard that provides immunity where a determination of unconstitutionality is not reasonably expected. This standard achieves a balance more consonant with our constitutional framework, similar to the balance the Court strikes over retroactivity in civil cases. For example, in Cheuron Oil Co. v. Hudson ${ }^{298}$ the Court stated that retroactivity would be denied only where a change in the law establishes "a new principle of law, either by overruling clear past precedent on which litigants may have relied or by deciding an issue of first impression whose resolution was not clearly foreshadowed."299 Such a standard in the immunity area would protect officers from changes in the law and other unpredictable developments, but it would impose liability where a right is likely to be recognized, even if the courts have not established it clearly. ${ }^{300}$

297 See, e.g., Arizona v. Youngblood, 109 S. Ct. 333, 337 (1988) (holding that absent bad faith, the failure to preserve potentially useful evidence does not constitute a due process violation); Batson v. Kentucky, 476 U.S. 79, 89 (1986) (holding that equal protecting forbids a prosecutor's discriminatory use of peremptory challenges); Wayte v. United States, 470 U.S. 598, 608 (1985) (limiting selective prosecution claims to cases in which the prosecutor was motivated by discriminatory purpose); Oregon v. Kennedy, 456 U.S. 667, 679 (1982) (barring a retrial after a mistrial caused by prosecutorial misconduct only where prosecutor "intended to provoke the defendant into moving for a mistrial"); Reiss, Prosecutorial Intent in Constitutional Criminal Procedure, 135 U. PA. L. REv. 1365, 1366 (1987) (contending that " $[w]$ here a criminal defendant challenges a prosecutorial action as unconstitutional, the courts tend to factor the prosecutor's intent into the calculus for deciding the constitutional claim").

298404 U.S. 97 (1971).

299 Id. at 106 (citation omitted).

300 A somewhat different standard applies in criminal cases. In Griffith v. Kentucky, 479 U.S. 314,328 (1987), the Court ruled that retroactivity is limited to cases in which the new decision marks a "clear break" from precedent. In Teague v. Lane, 109 S. Ct. 1060, 1078 (1989), the Court ruled that claims made in habeas corpus proceedings will not be adjudicated if they would establish new constitutional principles unless the principles are applied retroactively to all defendants similarly situated. A new constitutional principle "breaks new ground or imposes a new obligation on the States or the Federal Government" such that "the result was not dictated by precedent existing at the time." Id. at 1070. This standard closely resembles the test of Pierson v. Ray, 386 U.S. 547, 557 (1967), modified, Harlow v. Fitzgerald, 457 U.S. 800 (1982), in which the Court found immunity proper where a state statute authorizing the conduct was later declared unconstitutional. The Court has not applied even-handedly the immunity and retroactivity doctrine. In Goodman 
If the qualified immunity doctrine were modeled on the civil retroactivity doctrine it would not be necessary to incorporate a subjective good faith limitation on the defense. If the law were so unclear as to not provide reasonable grounds to predict the constitutional result, there would be little occasion for an officer to act maliciously or in bad faith. Under the current formulation, by contrast, there is frequent opportunity for bad faith actions, a fact recognized in Harlow and manifested in other cases. ${ }^{301}$ The Harlow/Anderson objective standard therefore needs the subjective prong to protect against the official who, aware of a constitutional ambiguity, intends to violate constitutional rights or acts in reckless disregard of whether a right exists. ${ }^{302}$

As noted above, the adoption of such a rule with its emphasis on the compensatory and deterrence policies of civil rights actions need not leave the public official who makes an Anderson- or Harlow-type constitutional misjudgment responsible for damages. The government can indemnify this official, and ensure full compensation to the victim for violation of her rights and insulate from damages liability the official acting in "good faith."303 Of course, even this manner of broadening the civil damages remedy for constitutional torts will not assure deterrence of official misconduct. As Professor Meltzer has commented, tort liability is insufficient absent "other influences reinforcing the incentive, created by potential tort liability, to avoid harm-causing activities."304 Unless governmental agencies properly

v. Lukens Steel Co., 482 U.S. 656, 660-64 (1987), the Court applied a newly announced statute of limitations retroactively in order to bar a civil rights claim, even though the law was unclear at the time the suit was brought and substantial reason supported the applicability of a longer statute.

301 See supra text accompanying notes 224-27.

302 Cf. Anderson v. Creighton, 483 U.S. 635, 664 n.21 (1987) (Stevens, J., dissenting) (noting the defendant's plainly erroneous statement that he had a right to enter a house without a warrant whenever he is looking for a fugitive).

303 See supra note 281.

304 Meltzer, supra note 43, at 286.

In cases involving private actors, one such force is an injurer's interest in self-preservation; but unlike careless drivers, police who engage in an unlawful search, or officials who engage in racial discrimination, do not expose themselves to a heightened risk of the kind of harm that they inflict. A second force, the discipline that the market imposes to reduce costs, applies at best indirectly to public employers. A third such force, moral inhibitions, also may be of limited strength, since law enforcement officials often believe that the constitutional rules limiting law enforcement practices are misguided. Finally, law enforcement activities are rarely subject to other regulatory devices like internal rulemaking.

Id. (footnotes omitted). 
discipline, retrain, and otherwise strictly supervise officers who engage in unconstitutional activity, we should not expect to see a substantial reduction in the incidence of official misconduct. ${ }^{305}$ Such corrective internal action may well be prompted by the high financial and political costs of failing to properly train, supervise, or discipline officials. $^{306}$

Qualified immunity provides an imperfect device for achieving the proper balance of the significant interests inherent in any scheme seeking to provide accountability for governmental misconduct. Limiting the breadth of the immunity defense along the lines suggested in this Article would vindicate important constitutional rights without sacrificing governmental interests of efficiency or fairness to officials.

305 See P. Schuck, supra note 43, at 98 ; Amsterdam, supra note 43 , at 790-91; Meltzer, supra note 43, at 285-86. See generally Fiss, The Supreme Court, 1978 Term Foreword: The Forms of Justice, 93 HARv. L. REv. 1, 28 (1979) (arguing that "[a] long term supervisory relationship develops between the judge and the institution" because "performance must be monitored, and new strategies devised for making certain that the operation of the organization is kept within constitutional bounds"). Imposition of municipal liability under Owen and Monell has prompted significant changes in police practices. A study conducted pre-Monell found that suits against individual officers had little impact on institutional policies. See Project, supra note 288, at 812-14. More recent studies credit the threat of municipal liability as an incentive to police departments to better train, supervise and discipline officers. See McCoy, Enforcement Workshop: Lawsuits Against Police-What Impact Do They Really Have?, 20 Crim. L. Bull. 49, 50-53 (1984); Schmidt, Section 1983 and the Changing Face of Police Management, in Police Leadership in America 226, 235 (W. Geller ed. 1985); see also Report Says Tighter Policies Reduce Killings by the Police, N.Y. Times, Oct. 20, 1986, at A20, col. 1 (attributing police leadership and new restrictive shooting policies, in part, to the financial influence of civil litigation).

306 See, e.g., Owen v. City of Independence, 445 U.S. 622, 652 (1980) (stating that "the threat that damages might be levied against the city may encourage those in a policymaking position to institute internal rules and programs designed to minimize the likelihood of unintentional infringements on constitutional rights"); Gity of Canton v. Harris, 109 S. Ct. 1197, 1204-05 (1989); Kerr v. City of West Palm Beach, 875 F.2d 1546, 1555 (11th Cir. 1989); Bordanaro v. McLeod, 87 I F. 2d 1151 (1st Cir. 1989), cert. denied sub nom. City of Everett v. Bordanaro, 58 U.S.L.W. 3190 (Oct. 3, 1989); Rodriguez v. Avita, 871 F.2d 552, 555 (5th Cir. 1989); Davis v. City of Ellensburg, 869 F.2d 1230, 1235 (9th Cir. 1989). 
